\title{
Investigating the Theoretical Constructs of a Green Lean Six Sigma Approach towards Environmental Sustainability: A Systematic Literature Review and Future Directions
}

\author{
Amna Farrukh ${ }^{1, *}$, Sanjay Mathrani ${ }^{1}$ and Nazim Taskin ${ }^{2}$ \\ 1 School of Food and Advanced Technology, Massey University, Auckland 0632, New Zealand; \\ s.mathrani@massey.ac.nz \\ 2 Management Information Systems Department, Bogazici University, Bebek, Istanbul 34342, Turkey; \\ nazimtaskin@gmail.com \\ * Correspondence: a.farrukh@massey.ac.nz
}

Received: 2 September 2020; Accepted: 2 October 2020; Published: 7 October 2020

\begin{abstract}
Green lean six sigma (GLSS) is an emerging approach towards environmental sustainability in conjunction with operational achievements. The success of this approach is premised on an understanding of the different components of a GLSS program; being the determinants for its outcomes. The aim of this paper is to investigate the various constructs of GLSS that play an essential role in achieving environmental sustainability. For this purpose, a systematic review of available literature has been conducted to evaluate the drivers, enablers (tools), and outcomes of a GLSS strategy as well as its critical success factors and barriers. Findings reveal that these constructs of GLSS as a holistic approach can facilitate an organization to better accomplish environmental objectives such as waste minimization, emission reduction, and resource conservation as compared to constructs of only one or any two of these strategies. Based on the analysis, an integrated GLSS framework is developed for environmental sustainability in addition to identifying vital research gaps and future directions.
\end{abstract}

Keywords: green; lean; six sigma; green lean six sigma; constructs; environmental sustainability; systematic literature review

\section{Introduction}

In the past few decades, organizations have implemented various improvement strategies globally to increase operational performance and achieve customer satisfaction [1]. Nowadays, customer awareness towards eco-friendly products and services, and worldwide environmental legislations are forcing organizations to synchronize their environmental goals with operational performance requirements [2,3].

Organizations operating in different areas such as manufacturing, healthcare, service, and education are confronting several environmental problems including operational wastes. Environmental problems are identified as greenhouse gas (GHG) emissions such as carbon dioxide $\left(\mathrm{CO}_{2}\right)$, methane $\left(\mathrm{CH}_{4}\right)$, and nitrous oxide $\left(\mathrm{N}_{2} \mathrm{O}\right)$ [4], generation of volatile organic compounds (VOCs), and water pollution $[4,5]$. These GHG emissions are not only generated during the manufacturing processes within the organization but also in supply chain activities while procuring material through logistics and transportation [6,7]. Along with these challenges, organizations also experience a global limitation of resources including energy, water, and raw material [8]. Additionally, sudden disruptions such as the current economic disturbance with a drastic increase in environmental awareness due 
to COVID-19 have emphasized the need for strategies that help organizations and governments in economic recovery together with environmental protection and resource conservation. A system is required that enhances the environmental performance of an organization without compromising the operational objectives [8].

Green lean six sigma (GLSS) has emerged as an approach towards achieving environmental objectives combined with operational performance [9]. It consists of tools and practices to achieve environmental performance by eliminating waste and conserving resources [10]. In the GLSS approach, green aims to reduce environmental wastes by executing environmental practices, lean decreases process wastes that helps in lowering environmental wastes, and six sigma contributes in minimizing defects and controlling process variation that leads to environmental waste reduction [11].

Literature regarding the green, lean, and six sigma strategies towards environmental problems include studies on linkages between lean and six sigma (LSS) [12], lean and green (LG) [13], and green lean six sigma [14]. Research also indicates the relationship of six sigma and green tools in gaining positive environmental effects [15]. There are numerous studies on the environmental performance achieved by utilizing these strategies separately [16-18]. However, there is a lack of literature on all three green, lean, and six sigma strategies as a combined holistic approach [19]. This gap is well highlighted in literature by several researchers such as Kumar et al. [20], Gaikwad and Sunnapwar [19], and Cherrafi et al. [21]. A combined GLSS approach is perceived as a potential strategy for the organizations towards environmental sustainability [22] as compared to the individual strategies or any of the two strategies. For example, lean six sigma lacks the ability of addressing life cycle impacts and managing environmental programs whereas green strategy can overcome this limitation by utilizing life cycle analysis (LCA) and environment management system (EMS) tools [11]. Similarly, if six sigma and green are combined, this approach is unable to highlight the lean process/production wastes that can have a major contribution on environmental performance [23].

Few studies have identified the theoretical constructs of a GLSS approach such as drivers, critical success factors (CSFs), tools and techniques, barriers, and outcomes individually [2,22,24,25]. However, there is little research that addresses the above GLSS constructs as a consolidated approach in reducing environmental impacts of organizations [10,19].

A systematic literature review has been conducted in this paper to investigate the existing studies on GLSS as an integrated concept. This paper investigates the drivers, enablers (tools), outcomes, CSFs, and barriers of a GLSS strategy which are the key components for realizing environmental benefits as well as identifies possible gaps and future research opportunities. The paper theoretically contributes to bridging the knowledge gap regarding the constructs of a holistic GLSS approach. Additionally, a holistic framework is developed that includes the GLSS constructs for achieving environmental sustainability. The research objectives of this paper are summarized as follows:

- To investigate the theoretical constructs (drivers, enablers, CSFs, barriers, and outcomes) of a holistic GLSS approach.

- To develop an integrated framework combining the above GLSS constructs as a holistic approach.

- To highlight the possible gaps and future research directions of a holistic GLSS approach.

The rest of the paper is structured as follows. Section 2 presents a literature review on green, lean, and six sigma strategies. Section 3 highlights the systematic literature review methodology used for this study. Section 4 represents the descriptive analysis of the selected articles and related findings. Section 5 entails a critical analysis of the green lean six sigma findings from literature. Section 6 highlights the gaps identified and future directions. Finally, conclusions and limitations of the study are presented in section seven. 


\section{A Review of Green, Lean, and Six Sigma Approaches towards Environmental Sustainability}

\subsection{Green Approach}

Green manufacturing as a philosophy determines, measures, evaluates, and controls the environmental wastes by solving problems associated with the products and processes [9]. The green concept has gained importance as it facilitates more and more organizations in minimizing their environmental impacts. A plethora of literature has emphasized the impact of green methods such as LCA, EMS, design for environment (DFE), energy management system (EnMS), and 3R (reducing, reusing, and recycling) on environmental performance [18,26-29]. These practices have positive outcomes in the form of conforming regulatory requirements, meeting customers' demands of environmental-friendly products, and achieving environmental certification [30]. The core objective of green approach is to minimize environmental impacts such as hazardous wastes, air emissions, health and safety risks to people and environment, and energy and resource conservation. Green wastes include pollution, unnecessary water consumption, air emissions, excessive energy and material utilization, eutrophication, and garbage [31]. Green manufacturing comprises various environmental initiatives in the form of green marketing, green packaging, green purchasing, green innovation, and green design [32]. The environmental initiatives in the form of EMS, eco-labelling, and environmental legislation have created a demand for green manufacturing in organizations [30].

\subsection{Lean Approach}

Lean manufacturing originated from Toyota Production System and gained recognition after the book entitled The Machine That Changed the World was published [33]. The lean philosophy works on "to do more with less" and minimizes waste in almost every area of an organization [30] (p. 410). Lean as a concept is based on the elimination of non-value added activities and can be described as a group of tools aimed to achieve the objectives of waste minimization and value addition [34]. Organizations implement lean strategy to create value for customers by minimizing lead time, reducing wastes, and improving flow of the process [14]. Moreover, value addition in lean manufacturing also includes providing value in products and services that reflect the environmental requirements from customers and initiatives taken by the organization [14].

Lean paradigm offers a variety of tools which can be utilized to reduce environmental impacts of manufacturing organizations [35]. These methods not only help organizations in achieving operational performance and gaining competitive advantage but also in accomplishing environmental targets [17]. Several studies have recognized the environmental advantages of lean practices by saving resources and energy $[17,36,37]$. In this regard, different examples of the lean tools are: total productive maintenance (TPM), Kaizen, 5S (seiri, seiton, seiso, seiketsu, shitsuke), value stream mapping (VSM), cellular manufacturing (CM), just-in-time (JIT), single minute exchange of die (SMED), visual management, and work standardization which have been utilized to enhance the environmental performance $[13,17,38]$.

\subsection{Six Sigma Approach}

Six sigma methodology was first introduced by Motorola, in 1987, in the manufacturing sector. The concept is based on the statistical process control (SPC) technique, which is used to reduce defects up to 3.4 parts per million opportunities and the term sigma is used to describe variation. It provides a systematic and structured approach of problem solving through the DMAIC process that includes define (D), measure (M), analyze (A), improve (I), and control (C) phases [39]. Six sigma not only helps in removing manufacturing defects in the production processes but also brings about improvements throughout the organization [40]. The core objectives of six sigma are to control process variation and defect reduction [41,42].

Although reducing environmental waste is not the primary objective of a six sigma approach, it is capable of achieving environmental performance such as reducing air emissions, energy consumption, and wastewater $[36,43,44]$. Process variation has a negative impact on overall environmental 
performance of an organization as deviating from the specifications results in defective products as well as resource and energy consumption [45]. Thus, the environmental impacts of six sigma are viewed as a "by-product" [36] (p. 10). By utilizing its tools in reducing defects, six sigma gains the objectives of resource conservation, air pollution, and waste minimization [36]. Literature also indicates the environmental benefits of six sigma methodology such as through use of pareto analysis, gage repeatability and reproducibility (gage R\&R), control charts, design of experiment (DOE), histogram, failure mode effect analysis (FMEA), DMAIC methodology, and supplier-input-process-output-control (SIPOC) diagram [16,43,46-48].

\subsection{Lean-Green Approach}

The difference between lean and green wastes is that the first is about non-value added activities and the second is about unnecessary usage of water, energy, and natural resources [49]. However, US Environmental Protection Agency (EPA) [50] presented a relationship between lean mudas and green wastes after an analysis of American firms which showed the simultaneous occurrence of the environmental wastes along with the lean wastes. Furthermore, the non-value-added activities could be regarded as a segment of wastage of power and natural resources. For instance, unnecessary movement of raw materials, work-in-process, and finished products are regarded as wastes from both lean and green perspective in terms of power consumption, gaseous emissions, and immoderate use of resources [51]. Based on the mutual objective of waste minimization, lean and green have been integrated into a joint strategy [14]. This synergistic relationship between lean and green not only achieves the environmental benefits but also reduces costs through waste minimization [1].

\subsection{Lean-Six Sigma Approach}

The integration of lean and six sigma is an established concept (i.e., LSS) and well acknowledged in literature [3]. The major common aspects of lean six sigma are waste minimization, continuous improvement, and customer satisfaction [52]. Since waste also includes rework and scrap which are often produced as a result of process variability, thereby, lean and six sigma are also connected [53]. Several organizations are developing a concurrent lean six sigma (LSS) approach, which integrates lean with six sigma as they contribute to a common objective of waste minimization [54].

\subsection{Limitations of Lean, Green, and Six Sigma Approaches}

Although, lean application has a positive and strong effect on environmental impact [36], research studies have emphasized that lean cannot fully remove the root causes of operational and environmental wastes, as it lacks a systematic and scientific approach in controlling manufacturing processes [55]. Further, lean individually cannot overcome problems of defect detection and reduction in the process to address environmental concerns [56]. On the other hand, green is incapable of addressing the variability issues in the process which leads to the environmental wastes [56]. While green manufacturing includes application of a decision support system and expert system [9], these techniques lack effective problem-solving approach [57]. Further, green manufacturing has limitations regarding the strategic concerns of an organization and decision making towards investment opportunities, for example, how to implement green practices in a manner that achieves the organizational goal towards environmental sustainability and profitability [58]. Similarly, six sigma alone cannot achieve the optimal environmental performance since it lacks the ability of addressing lean wastes in an organization and life cycle impact assessment related to products [59].

\subsection{Limitations of Lean-Green, Lean-Six Sigma, and Green-Six Sigma Approaches}

Due to the inherent limitations of the lean, green, and six sigma strategies, combinations of these strategies such as lean-green, lean-six sigma, and green-six sigma also experience limitations. For example, in the case of lean-green, although lean and green have the ability to identify wastes for environmental impacts, they usually do not present a structured problem-solving approach to waste 
reduction [60] nor are they able to control process variation [43]. Despite lean and green being closely related, they do not address root causes of a problem which is critical from a waste minimization aspect [9]. Therefore, studies have focused on combining six sigma with lean and green to resolve the above limitations of these strategies and enhance environmental sustainability [11,43]. Although, lean six sigma can enhance the environmental performance indirectly, environmental waste reduction is not the primary objective of LSS. This combination also lacks the ability of addressing life cycle impacts and deploying environmental improvement programs whereas green strategy can overcome this limitation by utilizing tools such as LCA, EMS, and DOE [11,59]. Similarly, if six sigma and green are combined then this combination may not be able to highlight lean wastes that have an indirect impact on environmental performance (as lean process/production wastes have a contribution on environmental wastes [23]). Lean can overcome this limitation through its waste analysis and management tools.

Garza-Reyes [9] has explained the relationship between green, lean, and six sigma by highlighting lean's role as an intermediate strategy for connecting green and six sigma. These three approaches are interrelated, adaptable, share common features, and overcome limitations of each other [11]. Due to these characteristics, green, lean, and six sigma strategies as a unified approach can address the aims of waste minimization, resource savings, and environmental impacts.

\subsection{Green Lean Six Sigma Approach}

The relationship among these three strategies can be better understood by their inherent characteristics of customer satisfaction achieved through waste reduction and value addition $[9,19]$. Each strategy in GLSS approach overcomes limitations of the other strategy to provide value by identifying and removing wastes resulting in environmental sustainability [19]. Waste has a different meaning within the green, lean, and six sigma strategies. In green manufacturing, waste is defined as environmental wastes and the green practices aim to remove these in order to fulfil customers' requirements of an environmentally safe product. Green strategy also includes the concept of green value addition (GVA) which adds value for the organization, stakeholders, and eventually for the environment [61]. Lean refers to the elimination of non-value added activities to satisfy customers and attempts to minimize various lean wastes [9]. On the other hand, six sigma enhances customer satisfaction by reducing defects (waste) which can result in a high-quality product. It generates value in the products and services through stable and reliable processes by reducing variation [32]. Although waste has different meanings in these strategies, the effect of waste is similar from "resource consumption" point of view, which is the ultimate impact of all these three strategies. In terms of environmental impacts of these strategies, green manufacturing clearly focuses on the environmental performance and resource conservation as one of its main dimensions [62]. Lean also saves resources by reducing waste, thus is recognized as an "environmental friendly method" [36] (p. 10). Similarly, six sigma signifies defect as material waste, space occupied, safety issue, and energy consumed [63]. The relationship between these three strategies is evident from Figure 1. 


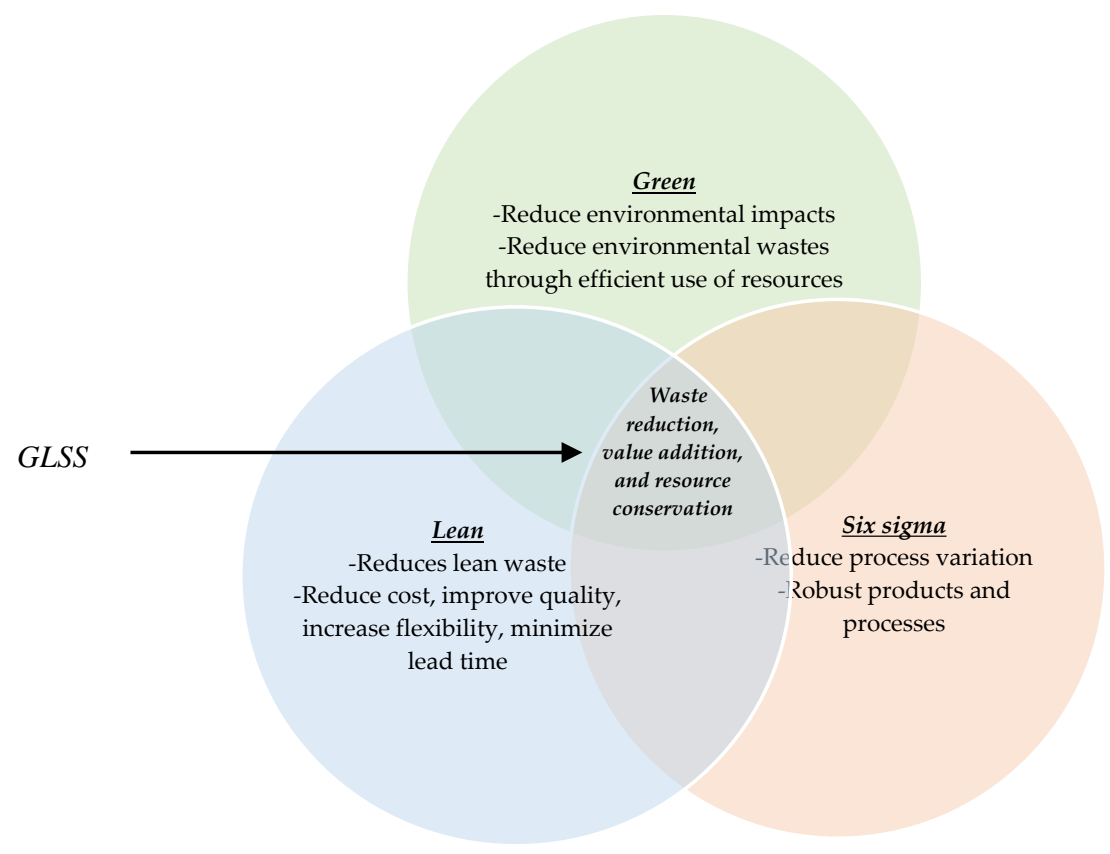

Figure 1. Objectives of green, lean, and six sigma and common aspects of GLSS, adapted from Snee [64], Dues et al. [65], and Kaswan and Rathi [22].

From the above discussion, the environmental performance can be improved if the green, lean, and six sigma strategies are combined to support each other as each of these has limitations. Although the practices associated with the green, lean, and six sigma strategies have positive environmental impacts, their combined effect is more significant as compared to individual practices [66].

\section{Research Methodology}

This paper uses a systematic literature review (SLR) methodology to conduct a comprehensive review of literature in a scientific and unambiguous manner in evaluating GLSS concept as an integrated approach [67]. SLR produces methodologically stringent research results as compared to ad hoc literature review with the aim of facilitating the evidence-based guidelines for researchers [68]. This paper uses the SLR methodology suggested by Tranfield et al. [67] which includes planning, conducting, and reporting the review as the key stages.

Planning stage: This stage specifies the need for this review and develops a literature review protocol as follows. This paper reviews the green lean six sigma as a consolidated approach towards environmental sustainability since there is a lack of research in this domain to holistically evaluate the green lean six sigma as one approach. The review protocol is given in Table 1.

Table 1. Review protocol.

\begin{tabular}{cc}
\hline Unit of analysis & Journal articles in green lean six sigma \\
\hline Type of analysis & Qualitative \\
\hline Time period & $1990-2020$ \\
\hline Search fields & Title, abstract, keywords \\
\hline Databases & Emerald, Science Direct, Scopus, and Web of Science \\
\hline Total number of articles used in this study & 58 \\
\hline
\end{tabular}

Conducting review: This stage includes collecting the studies and their analysis by extracting data. This literature review includes the journal articles from popular databases Emerald, Web of 
Science, Scopus, and Science Direct so that no relevant research is left from this study's point of view. Further, these databases provide a reference source of peer-reviewed literature. Only peer-reviewed journal articles have been selected to ensure the quality of the publications. The time period for selection is taken from 1990 to 2020. The year 1990 has been selected since the term "green" was first initiated in this year [69]. Further, the debate regarding lean and green relationship and their impact on environmental performance also started from this year $[19,70]$.

Table 2 represents keywords along with their respective notations. The keywords have been selected by a comprehensive review of available literature. A snowball approach has been applied in the search criteria of keywords [71] to further explore terms related to "green", "lean", and "six sigma". For example, "green" has been replaced with "environmental", "environmentally", "eco-sustainability", and "eco-efficiency". Similarly, "lean" has been replaced with "lean manufacturing", and "lean six sigma" and six sigma has been replaced with "lean six sigma". Articles have been searched from the above electronic databases by incorporating keywords in the following expressions 1,2,3, and 4 .

$$
\mathrm{X}=[\mathrm{L}, \mathrm{LM}, \mathrm{LSS}]
$$

where, $X[1]=\mathrm{L}, \mathrm{X}[2]=\mathrm{LM}, \mathrm{X}[3]=\mathrm{LSS}$

$$
\mathrm{XT}=\mathrm{X}[1]\|X[2]\| X[3]
$$

where, $\mathrm{T}=$ Total, $\|=\mathrm{OR}$

$$
Y=[G, E, E Y, E C, E S]
$$

where, $Y[1]=\mathrm{G}, \mathrm{Y}[2]=\mathrm{E}, \ldots . ., \mathrm{Y}[5]=\mathrm{ES}$

$$
\begin{gathered}
\mathrm{YT}=\mathrm{Y}[1]\|\mathrm{Y}[2]\| \mathrm{Y}[3]\|\mathrm{Y}[4]\| \mathrm{Y}[5] \\
\mathrm{Z}_{\mathrm{T}}=\mathrm{SS} \\
\mathrm{X}_{\mathrm{T}} \& \mathrm{Y}_{\mathrm{T}} \& \mathrm{Z}_{\mathrm{T}}
\end{gathered}
$$

where, \& $=$ AND

Table 2. Keywords and notations.

\begin{tabular}{cc}
\hline Keywords & Notations \\
\hline Lean & L \\
\hline Lean manufacturing & LM \\
\hline Lean six sigma & LSS \\
\hline Six sigma & SS \\
\hline Green & $\mathrm{G}$ \\
\hline Environmental & $\mathrm{E}$ \\
\hline Environmentally & EY \\
\hline Eco-efficiency & EC \\
\hline Eco-sustainability & ES
\end{tabular}

Other keywords such as "sustainable lean six sigma", "sustainable", "sustainability", "sustainable lean", "sustainable green lean six sigma", "sustainable six sigma" have been excluded as these sustainability-based phrases also include the social and economic dimensions, which are not a focus of this study. This approach is also consistent with Garza-Reyes [9] who conducted an SLR on lean and green by excluding the sustainability phrases. Furthermore, lean six sigma with environmental insights is regarded as green LSS [20], however, LSS in consideration of all three dimensions of triple 
bottom line (economic, societal, and environmental) is regarded as sustainable LSS [44]. The selection criteria also included English language for all the papers. This research criteria resulted into 179 journal articles including review articles.

To remove the duplicate papers, Endnote software has been utilized which resulted in the exclusion of 89 articles. After filtering the documents and applying the inclusion criteria, the abstracts of the papers were analyzed to align with the research topic, which led to elimination of 21 papers. Further, the full-text availability of the papers was considered resulting in exclusion of another seven papers. In the last stage, content of the articles was examined thoroughly according to the relevancy of the topic. This resulted into exclusion of further four articles out of which three articles having the keywords "environmental or environment" that referred to the organizational working environment, were eliminated. The last one was also excluded as this was out of the study's scope. The following Figure 2 has been developed by using the methodology of reporting systematic reviews-PRISMA (preferred reporting items for systematic reviews and meta-analysis) - and represents the filtration of articles [72].

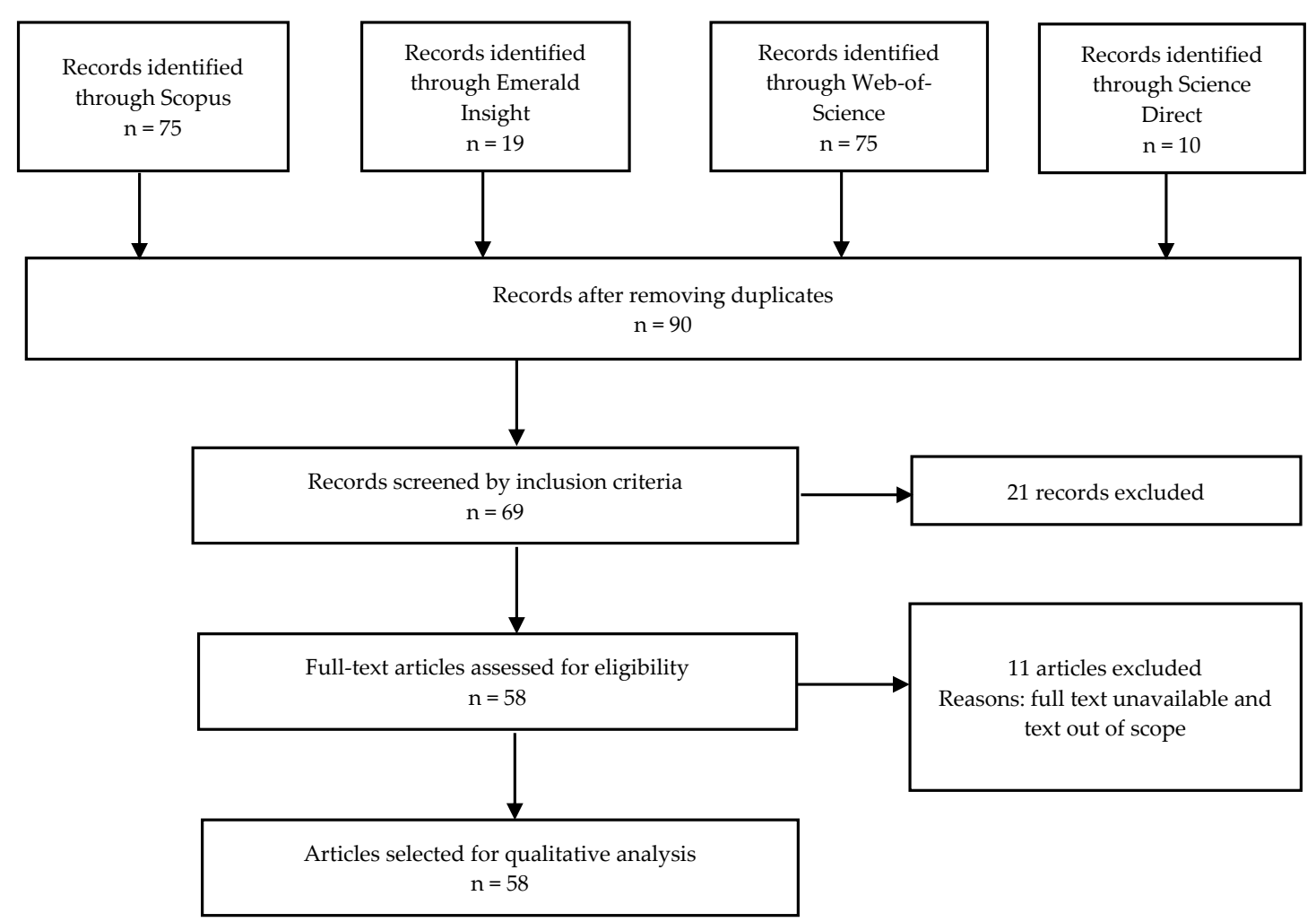

Figure 2. Preferred reporting items for systematic reviews and meta-analysis (PRISMA) flowchart.

The final sample comprised 58 articles, after comprehensive and careful consideration, that were highly relevant to the scope of the study. Although 10 percent of the usable articles are required for a precise analysis [36,73], we have considered all 58 articles since only a limited number of articles are available in this field. These articles have been analyzed in depth using Microsoft Excel. Each article has been categorized and organized by concepts. Data such as journal type, year of publication, authors, industry, country, research methodology, drivers, enablers, critical success factors, barriers, and outcomes have been extracted through a comprehensive reading of the full text of articles and complied into an all-inclusive Excel database for further analysis. The final sample of the articles are critically examined to gain an understanding of the GLSS approach for environmental sustainability in organizations. 


\section{Descriptive Analysis}

This section includes the descriptive analysis of 58 articles selected for a comprehensive literature review. Several tables and graphs on the categorization of GLSS literature have been presented which include the classification of the articles by year of publication, journal type, research methodology, industry, and country.

\subsection{Articles Classification by Year of Publication}

The number of articles published on GLSS by year can be seen in Figure 3. Although the start of the time period for this study is 1990, the articles on GLSS appeared by 2011. Moreover, there were only few articles published until 2015 and no article in 2013. After 2015, there was an increase in the number of articles and the maximum number of articles (12) were published in 2019. This increasing trend in GLSS research can be attributed to the growing interest of researchers and practitioners in this area and the rising concerns of organizations towards environmental sustainability.

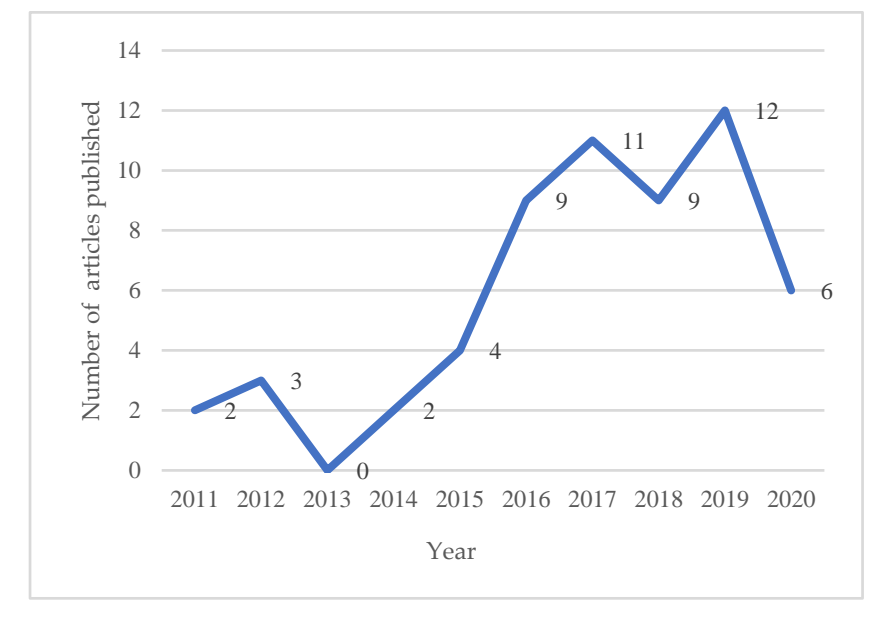

Figure 3. Articles distribution by year.

\subsection{Articles Classification by Journal}

The number of articles (in GLSS domain) published in the peer-reviewed journals can be observed from Figure 4. The chart clearly indicates that the maximum number of articles were published in the International Journal of Lean Six Sigma with 13 articles which is $22.41 \%$ of the total published articles, followed by Journal of Cleaner Production with five articles (8.62\%). Production Planning and Control and Total Quality Management \& Business Excellence contributed with four articles (6.89\%) each. Additionally, The TQM Journal, Sustainability, and International Journal of Productivity and Performance Management also contributed with two articles (3.44\%) each. The "Others" category in Figure 4 represents journals with single article publication.

\subsection{Articles Classification by Country}

With the increasing ecological awareness, both developed and developing countries are focusing towards the environmental performance in their organizational operations. Figure 5 shows a pie chart distribution of articles by country. It shows interesting results in this regard as most of the articles were published by a developing country, India, with total 18 articles (31.03\%), followed by the UK with nine articles (15.52\%). Further, there were seven articles (12.07\%) published by the USA and Brazil each, followed by Norway (5.17\%) and Morocco (3.45\%). In the chart, 12 articles appear under "Others" category which are single publications from several countries. 


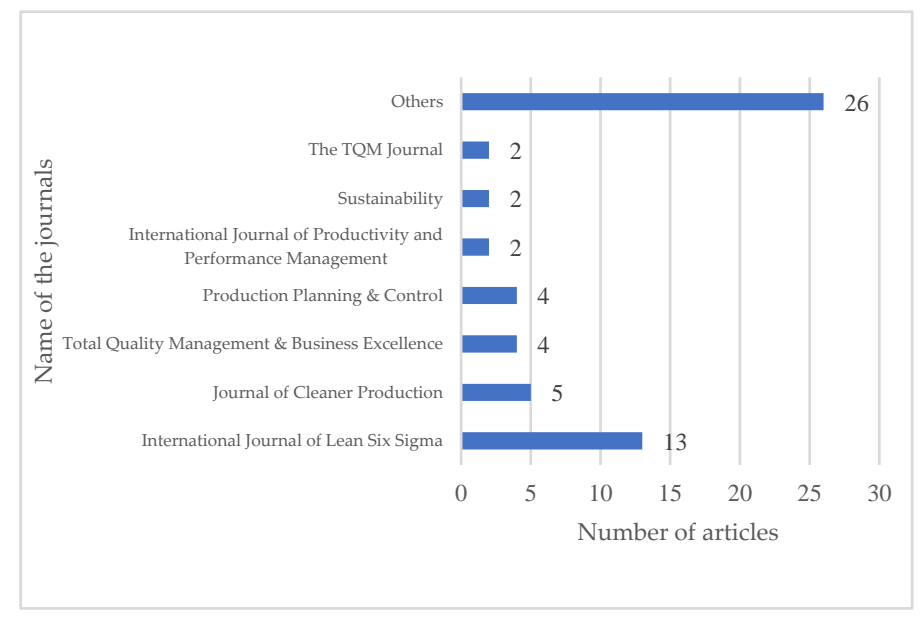

Figure 4. Articles distribution by journal type.

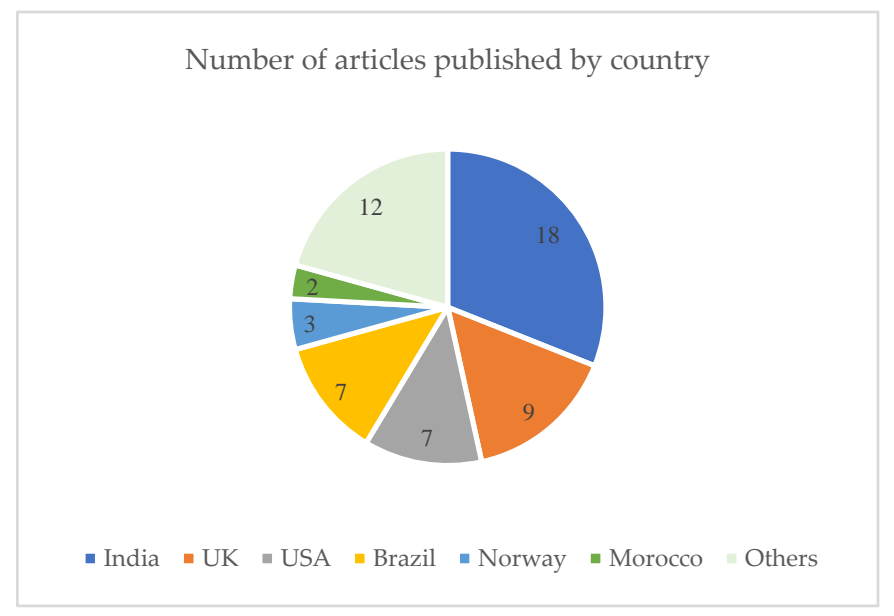

Figure 5. Articles classification by country.

Although, both developed and developing countries are trying to achieve environmental targets, GLSS considerations are more critical in developing countries due to their serious environmental impacts, waste management difficulties, and resource depletion issues [8]. Research on environmental aspects in developing countries is gaining popularity due to a number of reasons such as (a) the majority of the world population resides in these countries and (b) these countries are growing rapidly as compared to the developed countries [74]. According to an estimate, $90 \%$ of the world population will be residing in developing countries by 2050 [8].

Manufacturing companies consider developing countries as flourishing and cost-effective markets for expanding their facilities and trading their products. Leading manufacturing organizations are investing in these countries because of the high market growth potential (average annual growth rate approximately 7\%) [74]. Although there is potential for both international and national manufacturing companies to invest in developing countries, this poses a significant challenge in the form of environmental issues such as resource conservation, global warming, and climate change [74]. Moreover, in developing countries, energy consumption is three times more as compared to developed countries. Similarly, carbon emissions are four times more and water pollution six times more than developed countries [75]. 


\subsection{Articles Classification by Industry}

The distribution of the articles by industry sector is shown in Figure 6. It is clear that manufacturing is the prominent industrial sector (with nine articles) with most GLSS research. Then automotive industry along with healthcare have contributed with four articles each, followed by construction with three articles. Both aluminum and manufacturing and service industries have also contributed with two papers each. All other industrial sectors have single publications. The above classification of different industrial sectors is consistent with Parmar and Desai [3] in which automobile, construction, pharmaceutical, and petroleum industries were considered separate from manufacturing.

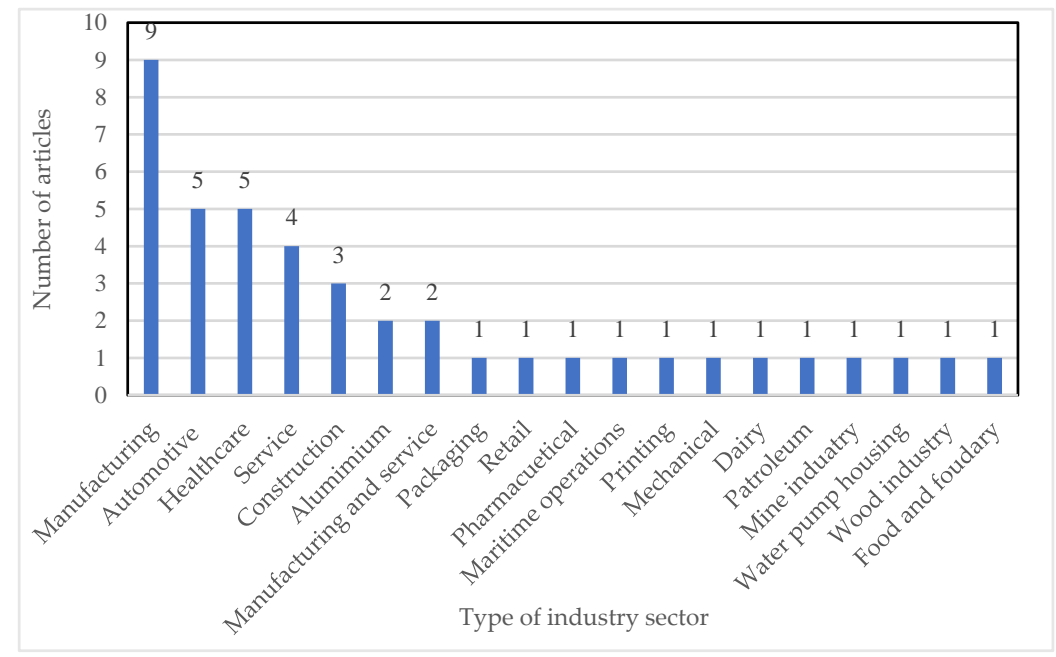

Figure 6. Articles distribution by industry sector.

\subsection{Articles Classification by Research Methodology}

The articles classification by research methodology is given in Figure 7. Various approaches have been utilized in GLSS research such as case study, survey, action research, modelling and simulation. There are articles that have utilized more than one method such as SLR and survey, survey and interview, survey and case study, and case study and simulation. The research articles that do not fit in the above categorization are kept under the "Others" category including literature review articles.

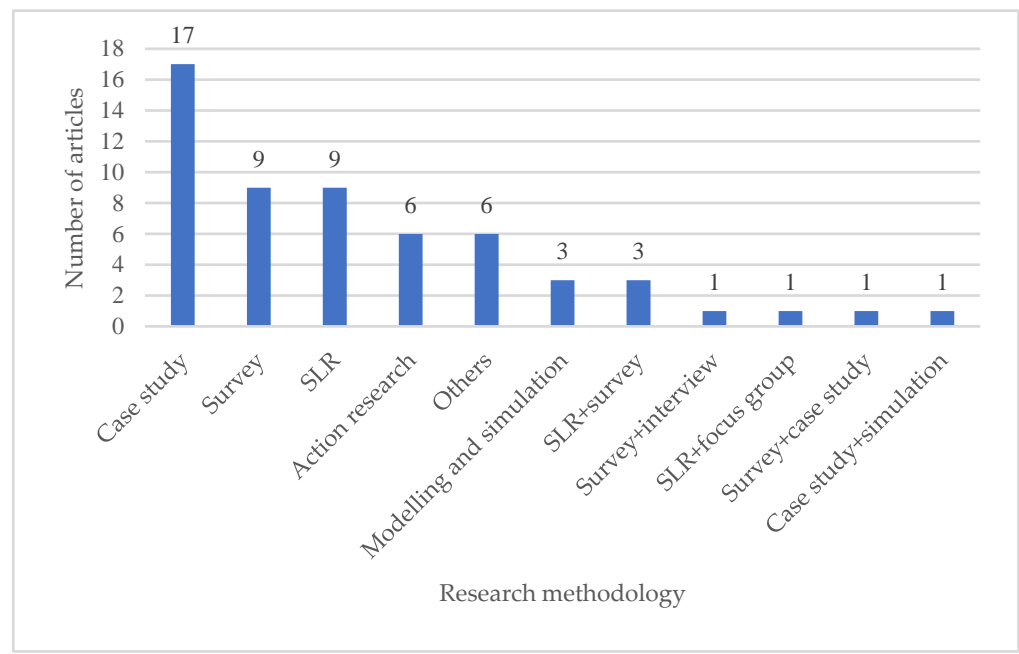

Figure 7. Articles classification by research methodology. 
The results of the analysis also highlight that the empirical data has been generated from 39 research studies including case study, survey, action research, and mixed-method approaches. It is evident that case study has been the most frequently utilized research methodology followed by survey and SLR. Case studies provide detailed information by utilizing several methods for data collection such as direct observations, interviews, audio visual, documents, participant observation, and organization's records [76,77]. Although interviews provide the most comprehensive information from case study respondents on a specific matter [78], the review of literature reveals only a few studies have utilized interviews as a data collection method $[14,79,80]$. The interviews with the experts and academics can provide an in-depth understanding of GLSS strategy which is lacking in literature. Furthermore, mathematical modelling and simulation is also essential as a robust methodological approach. On the other hand, SLR on this subject has also been utilized as a methodology by including green, lean, and six sigma strategies in green-lean, lean six sigma, and green-lean-six sigma combinations $[3,19,81,82]$. Such an SLR could be deemed as a superset of previous literature work, however, this research study is significant with its distinct characteristic of presenting GLSS as a combined approach in which this strategic combination has been thoroughly examined. Further, the theoretical constructs of this combination are deeply investigated resulting in a holistic GLSS framework for environmental sustainability.

\section{Analysis of the Research Findings}

\subsection{Drivers of Green Lean Six Sigma (GLSS) Approach}

Organizations are forced to align their processes according to environmental sustainability objectives due to the increasing cost of raw material and resource conservation issues [19]. Moreover, achieving financial performance, minimizing cost, and fostering a continuous improvement culture throughout the organization are key reasons for encouraging organizations to execute LSS practices $[3,83]$. Along with quality aspects and process improvement, increasing regulatory requirements and customers' environmental concerns have compelled organizations to initiate green practices [2]. However, findings reveal that there is a lack of research on GLSS drivers as a combined approach.

One longitudinal study conducted in a food company has identified the key driver as "an automatic escalation of the landfill tax" in a landfill reduction project [83] (p. 13). A few researchers have addressed internal and external drivers of GLSS which motivate organizations to make their operations environmentally sound [19,21]. Cherrafi et al. [21] have emphasized internal driving forces to initiate GLSS program such as increasing profitability, reducing cost, enhancing employee satisfaction, improving processes, and strengthening company image. Additionally, the external drivers of GLSS are highlighted as customer demands, regulatory requirements, shareholders' concerns, and competitive environment that motivate organizations to be more environmentally responsible $[1,19,21]$. Both the internal and external drivers can be interlinked to motivate the organizations towards integrating green, lean, and six sigma strategies [21]. An exploratory study conducted by Garza-Reyes et al. [2] in Chinese manufacturing organizations has determined the drivers as follows:

- Minimizing the barrier of market to enter international market.

- Sizing the environmental market prospects.

- Compliance with the regulatory requirements.

- Improving brand image.

- Meeting the customer requirements of environmental-friendly product.

- Social responsibility.

The major drivers identified in the above study include improving company image, social responsibility, and satisfying the customer demand for green products. 
The analysis of GLSS drivers from existing studies reviewed above concludes the key motivators as cost reduction, regulatory requirements, customer and stakeholder's demands for environmental-friendly products, company image, and profitability.

\subsection{Enablers of GLSS Approach}

GLSS enablers are a combination of various tools and techniques of green, lean, and six sigma that are utilized to enhance the execution of GLSS strategy. These tools are capable of identifying and removing environmental wastes along with achieving resource conservation objectives [22]. Figure 8 highlights GLSS tools in organizations according to their requirements and characteristics. The most frequently utilized tools are DMAIC, VSM, SIPOC, LCA, 5S, cause-effect diagram, pareto diagram, 5whys, 3R, EMS, FMEA, process maps, work standardization, and Kaizen. Findings highlight that these tools are mostly used under DMAIC methodology.

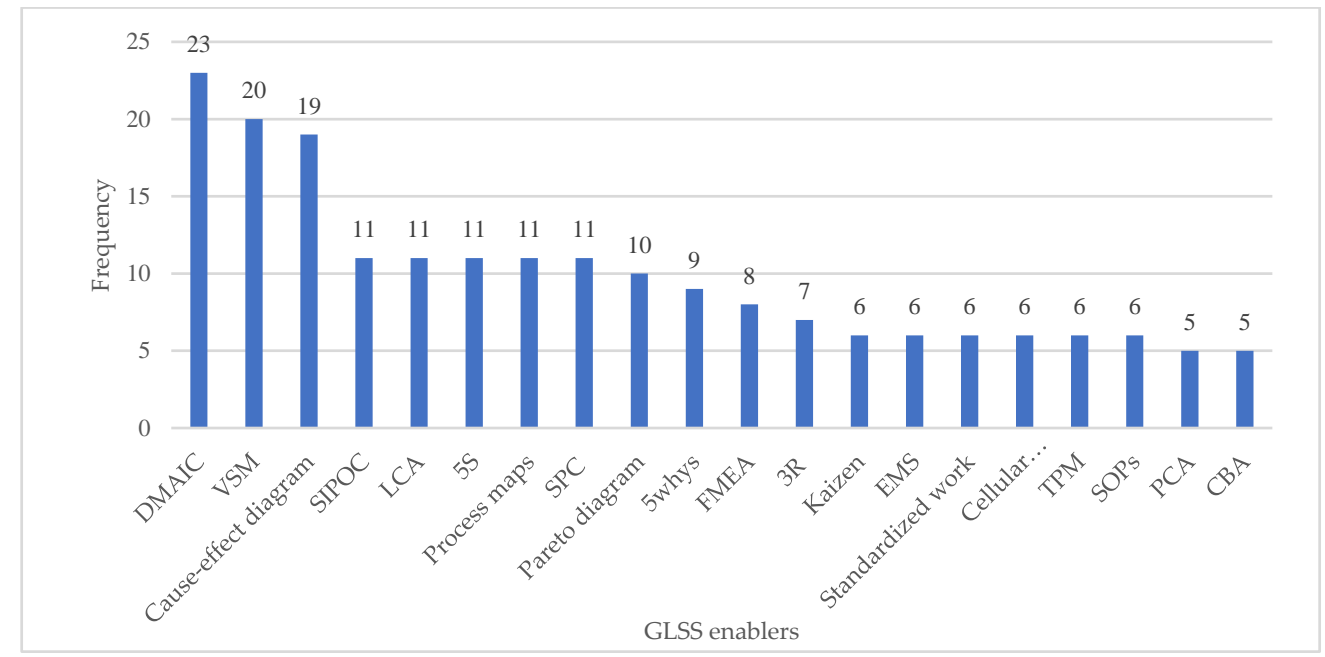

Figure 8. GLSS enablers addressed in articles.

Six sigma can facilitate green manufacturing by providing root cause analysis (cause-effect diagram) and data driven project management approaches (e.g., DMAIC and design for six sigma (DFSS)), which are lacking in the green strategy [9]. In this respect, six sigma can play a vital role in environmental projects. Further, environmental targets can be achieved if six sigma is integrated with EMS. This can result in environmental programs, documentation, and accurate planning based on the six sigma data driven approach [84]. An integrated model comprising EMS and six sigma has been developed and successfully implemented for lowering COD (chemical oxygen demand) level from 116 to $83 \mathrm{ppm}$ in an effluent treatment plant in India [85]. Quality function deployment (QFD) has also been utilized as an environmental tool in combination with LCA and recognized as a green quality function deployment (GQFD) approach [86]. QFD has a limitation that it does not address the life cycle impact of a product, therefore, merging with LCA is helpful. On the other hand, LCA is also unable to prioritize the design requirements which are overcome by integrating with QFD [59]. Consequently, both tools address the gaps of each other.

Findings have revealed that a combination of green, lean, and six sigma tools would bring more benefits as compared to tools from an individual approach, however, very few articles have integrated these tools for a combined effect $[11,45,87-89]$.

\subsection{Critical Success Factors of GLSS Approach}

To strengthen the relationships between green, lean, and six sigma approaches in aiding the outcomes, it is necessary for organizations to realize the success factors that are vital for the execution of GLSS program for environmental sustainability [90]. There exist few research studies that have 
identified the success factors of GLSS and investigated the interrelationship between the individual approaches. For example, Mishra [25] has identified five critical success factors of GLSS which are: (1) management and employee commitment, (2) organization's readiness to execute GLSS strategy, (3) selection and prioritization of GLSS projects, (4) provision of resources and training for GLSS implementation, and (5) focus on evaluation and results of GLSS program. Kaswan and Rathi [56] have determined 12 critical success factors and prioritize seven of these (based on experts' opinions) [90] by utilizing the best worst method (BWM), which can facilitate organizations in ranking these factors at the preliminary stage of GLSS program. The study finally concluded with three success factors as the crucial ones: (a) organization's willingness for GLSS performance measures, (b) leadership commitment towards environmental sustainability, and (c) the alignment of GLSS strategy with business objectives. The critical success factors of GLSS most discussed in literature are listed as "Top CSFs" in Table 3 according to their frequency of occurrence while the remaining are kept under the "Other CSFs" category.

Table 3. Critical success factors of GLSS.

\begin{tabular}{|c|c|c|c|}
\hline $\begin{array}{l}\text { Top Critical Success } \\
\text { Factors (CSFs) }\end{array}$ & References & Other CSFs & References \\
\hline $\begin{array}{l}\text { Management } \\
\text { commitment }\end{array}$ & $\begin{array}{l}\text { Cherrafi et al. [21], Chugani et } \\
\text { al. [36], Kaswan and Rathi [56], } \\
\text { Mishra [25], Powell et al. [44] }\end{array}$ & $\begin{array}{l}\text { Compliance to } \\
\text { regulatory requirements } \\
\text { and ethics relation }\end{array}$ & Caiado et al. [92] \\
\hline Training and education & $\begin{array}{c}\text { Caiado et al. [92], Ruben et al. } \\
\text { [81], Furukawa et al. [93] }\end{array}$ & $\begin{array}{l}\text { Corporate social } \\
\text { responsibility }\end{array}$ & Pandi et al. [94] \\
\hline Employee involvement & $\begin{array}{l}\text { Marrucci et al. [89], Caiado et } \\
\text { al. [79] }\end{array}$ & $\begin{array}{l}\text { System approach to } \\
\text { management }\end{array}$ & Pandi et al. [94] \\
\hline Organizational culture & $\begin{array}{l}\text { Erdil, et al. [95], Niñerola, } \\
\text { Ferrer-Rullan and Vidal-Suñé } \\
\text { [82] }\end{array}$ & $\begin{array}{l}\text { Effective jidoka } \\
\text { automation }\end{array}$ & Caiado et al. [92] \\
\hline $\begin{array}{l}\text { Effective measurement } \\
\text { system }\end{array}$ & $\begin{array}{c}\text { Ruben et al. [81], Kaswan and } \\
\text { Rathi [90] }\end{array}$ & $\begin{array}{l}\text { Understanding the } \\
\text { process }\end{array}$ & Ruben et al. [45] \\
\hline Teamwork & $\begin{array}{c}\text { Kaswan and Rathi [56], Ruben } \\
\text { et al. [81] }\end{array}$ & $\begin{array}{c}\text { Provision of suitable } \\
\text { solutions }\end{array}$ & Ruben et al. [45] \\
\hline Financial support & $\begin{array}{c}\text { Kaswan and Rathi [90], Ruben } \\
\text { et al. [91] }\end{array}$ & $\begin{array}{l}\text { Mindset of implementing } \\
\text { eco-friendly practices }\end{array}$ & Chugani et al. [36] \\
\hline Motivation & $\begin{array}{l}\text { Zhu et al. [80], Ruben et al. } \\
\text { [91] }\end{array}$ & Utilization of top talent & Ruben et al. [81] \\
\hline Knowledge management & $\begin{array}{c}\text { Caiado et al. [92], Ruben et al. } \\
\text { [81] }\end{array}$ & $\begin{array}{l}\text { Organizational learning } \\
\text { through human resource } \\
\text { development }\end{array}$ & Kaswan and Rathi [56] \\
\hline $\begin{array}{l}\text { Linking GLSS with } \\
\text { business strategy }\end{array}$ & Kaswan and Rathi [56] & Integration of GLSS & Kaswan and Rathi [56] \\
\hline $\begin{array}{c}\text { Readiness of } \\
\text { organization to } \\
\text { implement GLSS }\end{array}$ & $\begin{array}{l}\text { Kaswan and Rathi [56], Mishra } \\
\text { [25] }\end{array}$ & Integrated KPIs & Caiado et al. [92] \\
\hline Resource availability & Mishra [25] & Data assimilation & Kaswan and Rathi [56] \\
\hline $\begin{array}{c}\text { Awareness among } \\
\text { employees }\end{array}$ & Furukawa et al. [93] & & \\
\hline GLSS infrastructure & Ruben et al. [81] & & \\
\hline
\end{tabular}


Table 3. Cont.

\begin{tabular}{|c|c|c|c|}
\hline $\begin{array}{l}\text { Top Critical Success } \\
\text { Factors (CSFs) }\end{array}$ & References & Other CSFs & References \\
\hline Customer satisfaction & Caiado et al. [92], Pandi et al. [94] & & \\
\hline $\begin{array}{c}\text { Change in attitude and } \\
\text { behavior }\end{array}$ & $\begin{array}{l}\text { Portela, et al. [96], Caiado et al. } \\
\text { [92] }\end{array}$ & & \\
\hline Communication & Caiado et al. [92], Powell et al. [44] & & \\
\hline Rewards & Ruben et al. [81], Ruben et al. [91] & & \\
\hline $\begin{array}{l}\text { Appropriate project } \\
\text { selection }\end{array}$ & Mishra [25], Ruben et al. [81] & & \\
\hline Employee empowerment & $\begin{array}{l}\text { Caiado et al. [92], Caiado et al. } \\
\text { [79] }\end{array}$ & & \\
\hline $\begin{array}{l}\text { Analytical decision } \\
\text { making }\end{array}$ & Shokri and Li [1], Mishra et al. [97] & & \\
\hline Use of technology & Caiado et al. [79] & & \\
\hline $\begin{array}{c}\text { Green lean six sigma } \\
\text { metrics }\end{array}$ & Kaswan and Rathi [56] & & \\
\hline
\end{tabular}

\subsection{Barriers of GLSS Approach}

Although, GLSS is capable in addressing the issues of productivity, quality, efficiency, profitability, environmental sustainability, and competitiveness, execution of this approach is difficult due to the presence of certain barriers [24]. Findings from literature show that only a few studies have explored GLSS barriers [20,24,91]. Kumar et al. [20] have identified 21 barriers of GLSS in automobile industry of India by an extensive literature review and determined the hierarchy of these through ISM technique. Lack of top management support (comprising management involvement, initiatives taken by management, and management commitment) followed by lack of funds have been considered as crucial barriers. Further, lack of human resource management (including lack of training and education, lack of motivation and encouragement) and lack of continuous improvement (i.e., Kaizen) culture for both the employees and suppliers act as hurdles in the initiation of GLSS program.

Ruben et al. [91] have identified 20 barriers of LSS with environmental considerations by literature review. The study concluded that lack of top management commitment, lack of training and education, and lack of financial resources for environmental programs are key barriers in the implementation of GLSS approach. Similarly, a study conducted by Sreedharan et al. [6] have identified the following barriers from literature:

- Fear among manufacturers and suppliers regarding expenses associated with green supply chain activities (as they might become costly) and customers may not be able to afford it.

- The implementation of GLSS can be affected if employees are reluctant to adopt environmental practices.

- Lack of customers' trust on firm's green activities.

- Lack of supervision for executing green supply practices as a result of inappropriate policies.

- Lack of cooperation between public and private sector and lack of collaboration from international organizations (e.g., world trade organization (WTO), the European union (EU)) for a successful implementation.

- Lack of clarity on environmental sustainability which may lead to poor understanding of this approach.

- Difficulty of relating measures to customer satisfaction and lack of environmental knowledge in suppliers.

Hussain et al. [24] have determined 24 barriers through literature review. An interpretive structural modelling (ISM) based model indicating the complex relationship among these barriers has been 
developed where the base barrier is determined as "unstable political environment". The study revealed that the unstable political environment is the most critical barrier in the GLSS implementation in the construction sector of Pakistan followed by lack of government support, lack of customer involvement and awareness of GLSS, lack of leadership support for GLSS adoption, and lack of funds.

To overcome the lack of government support barrier, researchers have recommended various policies from government such as tax concessions, rewards, and subsidies [24]. Likewise, top management support could ensure training and brainstorming sessions, and consultation to the executive and senior management team for developing an understanding of sustainable environmental benefits [20,91]. Similarly, initiating environmental recognition programs and campaigns could increase customer and public awareness towards environmentally benign products [24]. The barrier, "lack of financial resources" could be overcome by generating funds from internal and external sources (e.g., loans) [20,24].

The review of the existing studies on GLSS barriers has revealed the key barriers as lack of top management support for environmental initiatives, lack of funds and resources, lack of awareness on environmental sustainability, lack of human resource management, and lack of infrastructure and continuous improvement culture for environmental practices.

\subsection{Outcomes of GLSS Approach}

The literature review also analyzes the environmental outcomes achieved by a GLSS strategy and are presented in Table 4. The analysis has indicated that energy reduction, waste reduction, emission reduction, and material and resource conservation are commonly addressed environmental outcomes of GLSS approach. However, other environmental performance measures such as use of environmentally safe material, water eutrophication, environmental compliance, waste disposal, environmental revenues, and water footprint are not frequently addressed due to a lack of research on environmental performance measures [82]. Further, authors have suggested a careful selection of environmental performance measures according to the organizations' and stakeholders' needs, external regulations, and organizational characteristics such as type of the organization, size of the company, industrial sector, and the corporate culture of the organization $[79,82]$.

\subsection{GLSS Models and Frameworks}

Findings from the analysis of 58 articles suggest that there is an increasing trend in GLSS research that is justified with the rising concerns in organizations to achieve better environmental performance. However, there is a lack of GLSS frameworks available in literature including a number of frameworks that have not been empirically tested from an industrial or real-life perspective $[1,6,9,19,81,92]$. Table 5 presents all GLSS frameworks available in literature and their context. This table also presents the limitations of these existing models. A few frameworks are oriented towards specific industries and are not generic, which could fit into any organizational environment. For example, Banawi and Bilec [11] have developed a lean green and six sigma framework for the construction industry. Similarly, one framework has been developed for the service industry [92] and another for the public sector [6]. The impact of digitalization and industry 4.0 on environmental sustainability in relation with GLSS is also lacking in literature since only one research study has been conducted in this area so far [98]. There are only three models for GLSS barriers and none of these have been validated from an industrial perspective. Similarly, there are three frameworks for CSFs of which one has been validated in the manufacturing sector and the others require industrial validation. The review of literature also shows that only one article has identified the drivers through exploratory study in this field. 
Table 4. Existing GLSS frameworks.

\begin{tabular}{|c|c|c|c|}
\hline Sr No. & Author & Description & Limitation \\
\hline 1 & Banawi and Bilec [11] & $\begin{array}{l}\text { Developed a framework for } \\
\text { the construction industry by } \\
\text { integrating green, lean, and } \\
\text { six sigma practices for } \\
\text { improving the process and } \\
\text { reducing environmental } \\
\text { waste. }\end{array}$ & $\begin{array}{l}\text { The framework requires } \\
\text { additional verification as it is } \\
\text { originally developed for the } \\
\text { construction industry and } \\
\text { entails considerable } \\
\text { implementation time. }\end{array}$ \\
\hline 2 & Garza-Reyes [9] & $\begin{array}{l}\text { The author highlighted the } \\
\text { need of integrating six sigma } \\
\text { with lean and green to } \\
\text { overcome their limitations. }\end{array}$ & $\begin{array}{l}\text { Validation of the proposed } \\
\text { concept is required in the } \\
\text { industrial sector through } \\
\text { empirical studies and } \\
\text { simulation and there is a } \\
\text { need to develop an } \\
\text { integrated model of green } \\
\text { lean six sigma as a single } \\
\text { approach. Further, the } \\
\text { framework lacks the } \\
\text { implementation of } \\
\text { assessment tools in different } \\
\text { phases. }\end{array}$ \\
\hline 3 & Cherrafi et al. [21] & $\begin{array}{l}\text { A framework has been } \\
\text { developed by integrating } \\
\text { green, lean, and six sigma } \\
\text { strategies based on a five } \\
\text { stage and } 16 \text { step process } \\
\text { and validated through a } \\
\text { research project in four } \\
\text { companies. }\end{array}$ & $\begin{array}{l}\text { The proposed framework } \\
\text { may not be suitable for } \\
\text { improving processes such as } \\
\text { painting, chemical treatment, } \\
\text { and metal finishing due to } \\
\text { their complex and sensitive } \\
\text { nature. }\end{array}$ \\
\hline
\end{tabular}

A hierarchical model comprising 21 barriers has been developed by utilizing interpretive structural modelling (ISM) technique in the green lean six sigma product development process for the automotive

The model has been based on experts' opinions, therefore, requires additional validation in industrial sectors. industry of India.

The authors have proposed to integrate six sigma with green lean to overcome their limitation of lack of controlling process variation

by utilizing measurement system analysis and gage control methodology. The model has been tested in a case study of a natural gas-powered boiler.

The authors have proposed a framework on knowledge based lean six sigma maintenance system for eco-sustainable buildings.

The authors implemented the proposed framework in an automotive plant with the aim of improving operational and and sigma levels by using various lean six sigma tools.

The execution of the framework has not been presented, and the study was confined to the pollution reduction project.

The model requires empirical validation in industrial sectors.

\section{The proposed framework} has been validated in a single automotive component manufacturing company and requires additional validation in other manufacturing

The authors have implemented VSM-DMAIC lean six sigma model in a dairy industry and achieved economic and environmental benefits.
Only one organization in the dairy sector has been considered and requires further investigation in other food and process industries. 
Table 4. Cont.

\begin{tabular}{|c|c|c|c|}
\hline Sr No. & Author & Description & Limitation \\
\hline 9 & Ruben et al. [81] & $\begin{array}{l}\text { The authors have conducted } \\
\text { a literature review and } \\
\text { proposed a GLSS framework } \\
\text { based on DMAIC } \\
\text { methodology }\end{array}$ & $\begin{array}{l}\text { The framework requires } \\
\text { validation through empirical } \\
\text { studies and simulation in } \\
\text { industrial organizations. }\end{array}$ \\
\hline 10 & Ruben et al. [91] & $\begin{array}{l}\text { The authors have identified } \\
20 \text { barriers regarding LSS } \\
\text { implementation with } \\
\text { environmental } \\
\text { considerations and } \\
\text { developed an ISM based } \\
\text { model. }\end{array}$ & $\begin{array}{l}\text { The ISM model has been } \\
\text { developed based on experts } \\
\text { opinions. Additional } \\
\text { validation through industrial } \\
\text { application and case studies } \\
\text { is needed. }\end{array}$ \\
\hline 11 & Caiado et al. [92] & $\begin{array}{l}\text { The authors have developed } \\
\text { an integrated GLSS } \\
\text { framework for service } \\
\text { organizations based on SLR. }\end{array}$ & $\begin{array}{l}\text { The framework was } \\
\text { developed for service } \\
\text { industry and requires } \\
\text { practical application and } \\
\text { statistical validation. }\end{array}$ \\
\hline 12 & Mishra [25] & $\begin{array}{l}\text { The authors have proposed a } \\
\text { GLSS implementation } \\
\text { framework based on the } \\
\text { critical success factors. }\end{array}$ & $\begin{array}{l}\text { The GLSS implementation } \\
\text { framework has not been } \\
\text { validated through industrial } \\
\text { application. Further, the } \\
\text { relationship between CSFs } \\
\text { need to be explored using } \\
\text { other modelling techniques. }\end{array}$ \\
\hline 13 & Sreedharan et al. [6] & $\begin{array}{l}\text { The authors have developed } \\
\text { a GLSS model of the green } \\
\text { supply chain for public } \\
\text { sector. The framework } \\
\text { comprises three stages with } \\
\text { a set of } 17 \text { activities. }\end{array}$ & $\begin{array}{l}\text { The proposed framework } \\
\text { has not been tested in } \\
\text { industrial sector and was } \\
\text { developed only for public } \\
\text { sector organizations. } \\
\text { Moreover, the framework } \\
\text { has not addressed the lean } \\
\text { green wastes. }\end{array}$ \\
\hline 14 & Zhu et al. [80] & $\begin{array}{l}\text { The authors have developed } \\
\text { a framework of integrating } \\
\text { green and lean for hospital } \\
\text { supply chain based on the } \\
\text { traditional IDEF meta model } \\
\text { comprising input, control, } \\
\text { mechanism, and output. } \\
\text { Additionally, the model has } \\
\text { been validated through three } \\
\text { case studies in different } \\
\text { hospitals. }\end{array}$ & $\begin{array}{l}\text { The framework has been } \\
\text { validated in healthcare } \\
\text { sector but requires } \\
\text { validation in other industrial } \\
\text { sectors. Additionally, the } \\
\text { propositions made in this } \\
\text { study need to be validated } \\
\text { by conducting further } \\
\text { studies and specific factors } \\
\text { need to be identified that } \\
\text { support the propositions. }\end{array}$ \\
\hline 15 & Kaswan and Rathi [56] & $\begin{array}{l}\text { The authors have developed } \\
\text { a GLSS enablers model } \\
\text { through interpretive } \\
\text { structure modelling. }\end{array}$ & $\begin{array}{l}\text { The model has been } \\
\text { developed based upon } \\
\text { experts' opinions, therefore, } \\
\text { requires additional } \\
\text { validation in industrial } \\
\text { sectors. }\end{array}$ \\
\hline 16 & Hussain et al. [24] & $\begin{array}{l}\text { The authors have developed } \\
\text { an ISM based model of GLSS } \\
\text { barriers according to the } \\
\text { construction industry of } \\
\text { Pakistan. }\end{array}$ & $\begin{array}{l}\text { The developed model and } \\
\text { identified barriers may not } \\
\text { be appropriate for other } \\
\text { industries as these were } \\
\text { investigated specific to } \\
\text { Pakistan's construction } \\
\text { sector considering its } \\
\text { industrial and cultural } \\
\text { characteristics. }\end{array}$ \\
\hline
\end{tabular}


Table 4. Cont.

\begin{tabular}{|c|c|c|c|}
\hline Sr No. & Author & Description & Limitation \\
\hline 17 & Sony and Naik [14] & $\begin{array}{l}\text { A GLSS implementation } \\
\text { framework has been } \\
\text { developed in which DMAIC } \\
\text { methodology is applied on } \\
\text { five principles of lean } \\
\text { thinking cycle. The } \\
\text { framework was designed to } \\
\text { achieve the five objectives of } \\
\text { environmental performance } \\
\text { and has been implemented } \\
\text { in an open cast mine } \\
\text { industry. }\end{array}$ & $\begin{array}{l}\text { A single case study has been } \\
\text { conducted to validate the } \\
\text { framework and consumed } \\
\text { considerable amount of time. } \\
\text { More studies are required in } \\
\text { different industrial sectors to } \\
\text { generalize the results. }\end{array}$ \\
\hline 18 & Mishra et al. [97] & $\begin{array}{l}\text { The authors have developed } \\
\text { a sustainable value stream } \\
\text { mapping framework } \\
\text { through simulation } \\
\text { modelling by ARENA to } \\
\text { evaluate the bonnet } \\
\text { manufacturing process from } \\
\text { lean and green perspectives. } \\
\text { They have compared the } \\
\text { current VSM and future } \\
\text { VSM of the process which } \\
\text { resulted in dramatic } \\
\text { operational and } \\
\text { environmental } \\
\text { improvements. }\end{array}$ & $\begin{array}{c}\text { A limitation of the study was } \\
\text { that a single case study has } \\
\text { been conducted to validate } \\
\text { the model and mainly lean } \\
\text { tools are addressed in the } \\
\text { study. }\end{array}$ \\
\hline 19 & $\begin{array}{c}\text { Gaikwad and Sunnapwar } \\
\text { [19] }\end{array}$ & $\begin{array}{l}\text { The authors have conducted } \\
\text { a SLR and presented a } \\
\text { framework for Indian } \\
\text { manufacturing industries. }\end{array}$ & $\begin{array}{l}\text { The framework requires } \\
\text { empirical validation in } \\
\text { industrial sectors. }\end{array}$ \\
\hline 20 & Shokri and Li [1] & $\begin{array}{l}\text { The authors have proposed a } \\
\text { hybrid approach of green } \\
\text { LSS projects and developed } \\
\text { a mathematical model to } \\
\text { facilitate decision making } \\
\text { under LSS projects by which } \\
\text { the final outputs can also be } \\
\text { environmentally friendly. } \\
\text { The volume of production } \\
\text { and final price of products } \\
\text { for consumers are } \\
\text { characterized as "mediating } \\
\text { factors" to balance the LSS } \\
\text { projects' operational outputs } \\
\text { and environmental } \\
\text { performance. }\end{array}$ & $\begin{array}{l}\text { Empirical data and case } \\
\text { studies are needed for } \\
\text { validation by utilizing the } \\
\text { analytical model. Moreover, } \\
\text { the factors such as price, } \\
\text { volume, and energy should } \\
\text { also be considered as } \\
\text { indicators in the "sustain" } \\
\text { stage of the DMAIC cycle. }\end{array}$ \\
\hline
\end{tabular}


Table 5. Environmental outcomes achieved by GLSS approach.

\begin{tabular}{|c|c|c|c|}
\hline $\begin{array}{l}\text { Environmental } \\
\text { Outcomes }\end{array}$ & References & $\begin{array}{l}\text { Environmental } \\
\text { Outcomes }\end{array}$ & References \\
\hline Energy reduction & $\begin{array}{c}\text { Tasdemir and Gazo [88], } \\
\text { Cherrafi et al. [21], } \\
\text { Fatemi and Franchetti } \\
\text { [99], Kendrick et al. } \\
\text { [100], Mishra et al. [97], } \\
\text { Sagnak and Kazancoglu } \\
\text { [43], Zhu et al. [80] }\end{array}$ & $\begin{array}{c}\text { Reduction in GHG } \\
\text { emission (carbon } \\
\text { monoxide, nitrous oxide) }\end{array}$ & $\begin{array}{l}\text { Sagnak and Kazancoglu } \\
\text { [43], Marrucci et al. [89] }\end{array}$ \\
\hline Waste reduction & $\begin{array}{c}\text { Cherrafi et al. [21], } \\
\text { Powell et al. [44], } \\
\text { Ratnayake and Chaudry } \\
\text { [101], Tasdemir and } \\
\text { Gazo [88] }\end{array}$ & $\begin{array}{c}\text { Increase in } \\
\text { reusable/recyclable } \\
\text { material }\end{array}$ & $\begin{array}{l}\text { Sagnak and Kazancoglu } \\
\text { [43] }\end{array}$ \\
\hline $\begin{array}{l}\text { Material and resource } \\
\text { conservation }\end{array}$ & $\begin{array}{l}\text { Cherrafi et al. [21], } \\
\text { Kendrick et al. [100], } \\
\text { Sagnak and Kazancoglu } \\
\text { [43], Zhu et al. [80] }\end{array}$ & Pollution/air acidification & $\begin{array}{l}\text { Sagnak and Kazancoglu } \\
\text { [43], Mishra et al. [97] }\end{array}$ \\
\hline Carbon footprint & Mishra et al. [97] & $\begin{array}{l}\text { Reduction in disposal } \\
\text { cost }\end{array}$ & Deanna Martin [102] \\
\hline Increase in recycling & $\begin{array}{l}\text { Marrucci et al. [89], } \\
\text { Portela et al. [96] }\end{array}$ & $\begin{array}{c}\text { Use of } \\
\text { environmental-friendly } \\
\text { material }\end{array}$ & Kendrick et al. [100] \\
\hline Emission reduction & $\begin{array}{l}\text { Zhu et al. [80], Kendrick } \\
\text { et al. [100], Sony and } \\
\text { Naik [14], Tasdemir and } \\
\text { Gazo [88], Fatemi and } \\
\text { Franchetti [99] }\end{array}$ & Landfill reduction & Chaplin and Rourke [83] \\
\hline $\begin{array}{l}\text { Reduction in the use of } \\
\text { hazardous chemical }\end{array}$ & Belamkar [103] & Incineration & Marrucci et al. [89] \\
\hline $\begin{array}{l}\text { Reduction in water } \\
\text { consumption }\end{array}$ & $\begin{array}{l}\text { Sagnak and Kazancoglu } \\
\text { [43], Cherrafi et al. [21] }\end{array}$ & $\begin{array}{l}\text { Additional income from } \\
\text { recycling }\end{array}$ & Chaplin and Rourke [83] \\
\hline Water eutrophication & Mishra et al. [97] & $\begin{array}{c}\text { Environmental risk } \\
\text { assessment }\end{array}$ & Cherrafi et al. [21] \\
\hline Water footprint & Tasdemir and Gazo [88] & $\begin{array}{l}\text { Reducing airborne } \\
\text { particulates }\end{array}$ & Chaplin and Rourke [83] \\
\hline Wastewater reduction & Powell et al. [44] & $\begin{array}{l}\text { Environmental cost } \\
\text { reduction }\end{array}$ & Sony and Naik [14] \\
\hline Waste disposal & Furukawa et al. [87] & $\begin{array}{l}\text { Increase environmental } \\
\text { revenues }\end{array}$ & Sony and Naik [14] \\
\hline Defect reduction & Powell et al. [44] & $\begin{array}{l}\text { Environmental } \\
\text { compliance }\end{array}$ & Tasdemir and Gazo [88] \\
\hline $\begin{array}{l}\text { Decrease in } \\
\text { transportation }\end{array}$ & Tasdemir and Gazo [88] & Company image & Garza-Reyes et al. [2] \\
\hline $\begin{array}{l}\text { Reduction in hazardous } \\
\text { waste }\end{array}$ & Portela et al. [96] & Stakeholder satisfaction & Garza-Reyes et al. [2] \\
\hline
\end{tabular}

\subsection{An integrated GLSS Framework towards Environmental Sustainability}

After examining the limitations of the existing studies, evaluating the strengths associated with the green, lean, and six sigma strategies, and investigating the drivers, enablers, outcomes, CSFs, and barriers of GLSS, it can be concluded that a combined GLSS approach is needed for optimal environmental sustainability benefits. Figure 9 presents a holistic GLSS framework comprising an integrated GLSS approach at the core in combination with theoretical process constructs including the key drivers, enablers, CSFs, barriers, and outcomes. 


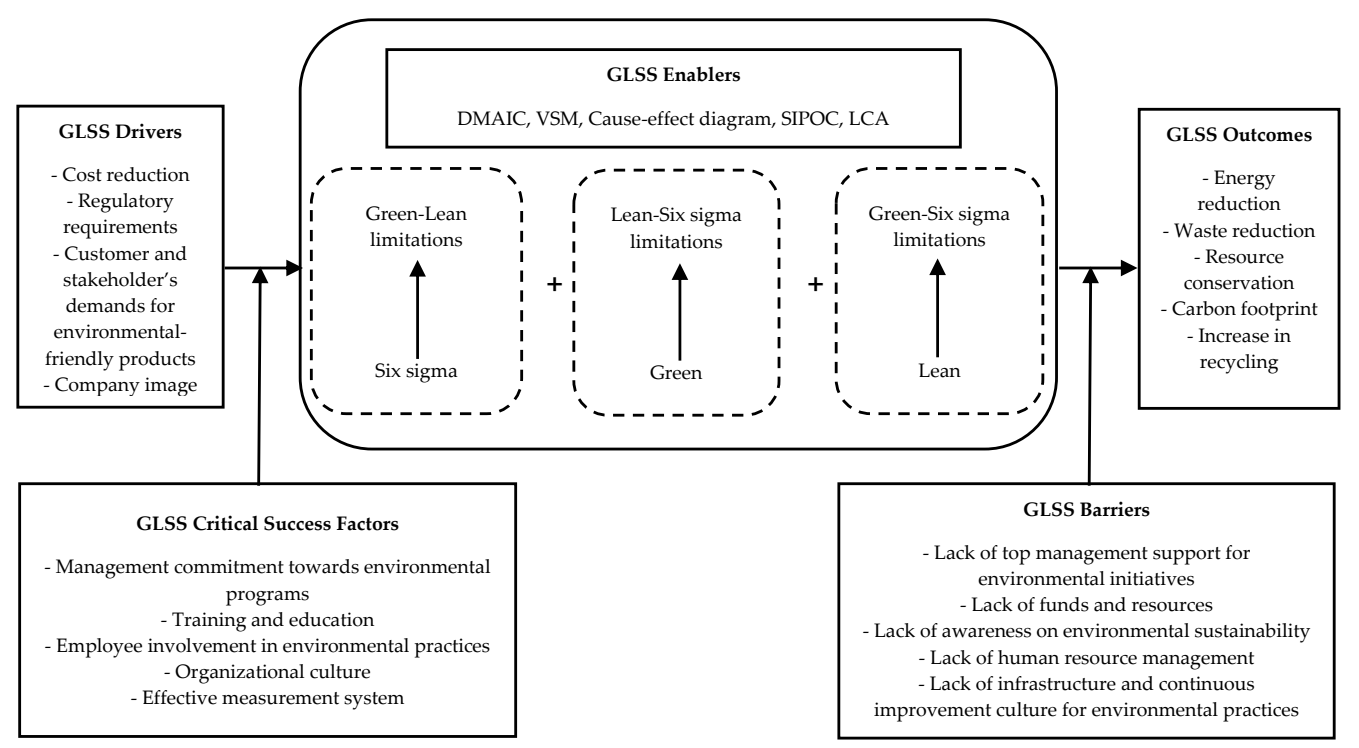

Figure 9. An integrated GLSS approach towards environmental sustainability.

The integrated GLSS approach facilitates the green, lean, and six sigma strategies in overcoming the limitations of green-lean, lean-six sigma, and green-six sigma in achieving environmental outcomes. The proposed framework is an arrangement of the GLSS components that strengthen the connection and relationship between these three strategies. This framework has been designed after an extensive literature review and evaluation of existing frameworks [10,19]. It consists of three stages which lead one to the other. First, the GLSS drivers motivate an organization to undertake environmental initiatives. In the next stage, the GLSS enablers help an organization to execute plans and activities for achieving environmental sustainability. The arrows in the central part of the model depict the support from green, lean, and six sigma (individually) in overcoming the shortcomings of these strategies in different combinations to emerge as an integrated GLSS strategy. Finally, in the last stage, the GLSS outcomes are achieved in the form of environmental sustainability by the actions taken utilizing the GLSS strategy. In addition to this framework, the CSFs play an intermediate role to ensure the effective implementation of the GLSS enablers. The barriers perform as impeding factors to impact the environmental performance of the organization and must be overcome by developing policies and guidelines. The success of this combined approach depends on an assessment of the drivers, enablers (tools), critical success factors, barriers, and outcomes. These components work together in a holistic manner to facilitate the organizations in achieving environmental sustainability.

\section{Future Directions}

Based on the above analysis and careful investigation of selected studies, the following future research directions are suggested in the GLSS domain.

\subsection{Theoretical Constructs of GLSS}

This literature review survey has revealed that there is a lack of studies on the drivers, success factors, enablers, outcomes, and barriers for a holistic GLSS approach towards environmental performance. More research regarding these aspects will assist organizations in making sound decisions and understanding the GLSS strategy. Furthermore, it will be beneficial for organizations to strategically analyze their resources for efficient and effective consumption. Future research must include evaluating the interrelationship between various drivers, enablers, outcomes, success factors, and barriers of GLSS using appropriate modelling techniques.

Although GLSS strategy brings numerous environmental benefits, there is a need to explore the negative impacts of the GLSS practices in different industries. For example, JIT practices are not 
suggested to be helpful in reducing environmental impacts rather it increases air emissions through frequent replenishments and transportation [105], although have benefits in using less space, energy, obsolescence, wastage, and material handling. Similarly, more investigation is required about SMED's effect on environmental performance since according to a few researchers, there are not significant environmental outcomes achieved by this tool $[37,106]$. Therefore, further research in GLSS tools can provide more insights to organizations in the execution of this strategy. There is a need to conduct more research on other GLSS tools as well, which have not been studied much but commonly used from literature such as process capability analysis, DOE, Kanban, Taguchi method, Kano model, 5R (reduce, reuse, recycle, redesign, remanufacture), DFE, Takt time, and EnMS. Additionally, careful selection of GLSS tools according to project characteristics is mandatory for the success of GLSS strategy in achieving positive environmental impacts. GLSS projects comprise a team of environmental experts and LSS experts [21], however since green, lean, and six sigma emerges as a holistic approach towards environmental performance, there could be a new breed of GLSS consultants who would be experts in executing this integrated approach.

\subsection{Discrete vs. Process Industry}

Manufacturing organizations whether discrete or process have environmental impacts. Findings also reveal that the majority of research is done in discrete manufacturing opposed to process industry. Manufacturing organizations in process industry such as petroleum refining, metal processing, mineral processing, chemical production, plastics, and paper manufacturing have significant environmental impacts and these sectors are highly energy intensive [107]. In addition to serious environmental effects, manufacturing firms within the process industry consume large amounts of energy and resources. The lack of visibility, far reaching errors, and long-time duration of manufacturing operations are critical challenges in the process industry as compared to discrete [44]. Therefore, there is a need to research on the significance of a GLSS strategy in process industry. Further, comparative studies between discrete and process industries on GLSS application can increase the depth of knowledge in this domain. Additionally, there is a need to consider organizational characteristics such as large enterprises and small to medium enterprises (SMEs) while comparing the organizations and industries.

\subsection{Current Trends under GLSS}

GLSS is not only utilized in the manufacturing, automotive, service, and healthcare sectors but can also achieve environmental benefits in other sectors such as construction [20,24], petroleum [101], food [83], and packaging [89]. Moreover, production operations and other functions such as product development [20] and supply chain management [6] are also realizing environmental outcomes.

Technological advancements in green manufacturing play a considerable role in increasing environmental impact such as in application of renewable energy, recycling, and waste management systems [108]. Digitalization and sustainability are becoming a major concern for organizations due to their impact on "production chain" [109] (p. 75). Both digitalization and sustainability inherent practices such as lean-green integration, remanufacturing and recycling, and design for disassembly. With the emergence of industry 4.0 infrastructure, IT facilitates organizational operations in new ways. Various technological developments such as cloud manufacturing, cyber-physical systems (CPS), 3D printing, artificial intelligence (AI), electric vehicles (EV), big data analytics (BDA), and augmented reality assist in the development of industry 4.0 solutions [110-113]. For example, BDA helps organizations in the collection, arrangement, and analysis of large sets of data to observe data patterns and information for future decision making [113]. Similarly, 3D printing can facilitate suppliers in minimizing lead times, reducing costs, and increasing the availability of parts [109]. Industry 4.0 has a positive influence on environmental dimension of sustainability by reducing waste, conserving resources, and predicting energy consumption [113-115]. There should be more research in application of GLSS in industry 4.0 practices to enhance environmental performance. One example is a recent study 
conducted in an effort to integrate big data analytics with green and lean six sigma [98]. The authors conducted a survey research in order to determine the impact of BDA on environmental performance and how LSS and green manufacturing supports this cause. Different constructs of BDA, LSS, green, and environmental performance were developed, and hypothesis was tested. The study results have revealed that BDA capabilities have a direct impact on LSS, green, and environmental performance. The results also highlight an indirect impact of BDA on environmental performance by integrating it with either LSS or green, or both. Many knowledge-based systems are centered on artificial intelligence, which aid in strong decision support. These systems are widely used in areas of healthcare, banking, and engineering to accelerate reliable decision making [104]. Future research in GLSS must also include deployment of knowledge-based systems in conjunction with the knowledge and skills of LSS and environmental experts to foster environmental sustainability.

With an increasing demand for improving environmental performance, organizations are becoming more conscious towards circular economy (CE). The objectives of $\mathrm{CE}$ are in reducing wastes and environmental emissions, conserving resources and materials, and achieving sustainability [32]. Green manufacturing is also regarded as a facilitator of $\mathrm{CE}$ along with environmental improvement and has emerged as a "strategic weapon" for organizations [32] (p. 1282). A good example of circularity in this perspective is $3 R$ practices to reutilize resources in manufacturing systems [116]. Material criticality issues (such as risks associated with shortage, supply, and price increase of materials) in a circular economy can also be addressed by lean and six sigma strategies [116]. Lean manufacturing complements the circular economy objectives as it focuses on the waste minimization and value creation principles [117]. Further, lean manufacturing not only reduces consumption and wastes associated with raw material (virgin materials), but also considers the circular economy perspective of resource conservation. In this respect, it works on the effective utilization of material generated from waste treatment (recycling, recovery), which becomes the input for next life cycles of products [117]. Additionally, DFSS has been applied in evaluating a product quantitatively by including the recovery aspects of circular economy [118]. According to the European Commission report on the implementation of circular economy [119], there is a need of a systematic approach for the execution of circular economy objectives. The environmental objectives achieved by green, lean, and six sigma strategies in the form of minimizing environmental impacts and resource conservation can provide a gateway towards circular economy. However, there is a lack of literature in the role of a holistic GLSS approach in circular economy models [89]. The application of a GLSS strategy to circular economy can result in increased environmental performance along with resource conservation by utilizing reusable and recyclable materials.

\section{Conclusions and Limitations}

Environmental sustainability has been regarded as one of the strategic priorities for organizations, which needs to be aligned with the traditional operational performance objectives of cost reduction, profitability, and customer satisfaction $[9,44]$. Findings from this study highlight that a holistic GLSS approach fulfils the necessities of environmental performance together with operational objectives. The outcomes of this approach fetch more benefits than implementing only one strategy or any two of the strategies. For example, LSS can achieve environmental performance by reducing process wastes and defects, however, it lacks in aspects of the life cycle analysis, design for environment and environmental management programs which are core objectives of the green strategy. Thus, the benefits of GLSS as a holistic approach over LSS are in addressing the above limitations and achieving environmental benefits along with operational performance.

This study has helped in investigating the theoretical constructs-drivers, CSFs, enablers, barriers, and outcomes-for an integrated GLSS approach in achieving environmental sustainability through a systematic literature review. The exploration of these constructs provides deep insights into the impact of a GLSS strategy on utilizing resources, adding value, managing wastes, and the resulting environmental performance. This study has emphasized how a combined GLSS approach can be useful 
in addressing the environmental dimensions of waste minimization, environmental protection, and resource conservation. An integrated GLSS framework is developed for environmental sustainability as a result of this study establishing the relationships among these strategies, which has been largely lacking in literature. The review conducted on 58 articles has also revealed the following: (a) An increasing trend in the GLSS research, (b) maximum publications in the GLSS domain by International Journal of Lean Six Sigma, (c) manufacturing as the prominent sector in GLSS research, and (d) case study as the commonly used research methodology. However, this research is limited by the use of only journal articles in the review. Further, the economic and societal dimensions of sustainability are not considered as per scope of this study.

The review has identified future directions and emerging trends in GLSS which are useful for researchers in this field. Researchers can use the integrated GLSS framework developed in this paper (Figure 9) for future empirical studies. Findings from this study will also assist practitioners in organizations in establishing decisions towards implementing a GLSS approach for environmental benefits. Overall, this study is helpful to both academia and practitioners in understanding the holistic impact of an integrated GLSS approach towards environmental sustainability.

Author Contributions: Conceptualization, A.F. and S.M.; literature review, A.F.; methodology, A.F., S.M., and N.T.; formal analysis, A.F.; investigation, A.F., S.M., and N.T.; software, A.F.; writing draft, A.F. and S.M.; supervision, S.M. and N.T.; validation, A.F., S.M., and N.T.; All authors have read and agreed to the published version of the manuscript.

Funding: This research received no external funding.

Conflicts of Interest: The authors declare no conflict of interest.

\section{References}

1. Shokri, A.; Li, G. Green implementation of Lean Six Sigma projects in the manufacturing sector. Int. J. Lean Six Sigma 2020. [CrossRef]

2. Garza-Reyes, J.A.; Yu, M.; Kumar, V.; Upadhyay, A. Total quality environmental management: Adoption status in the Chinese manufacturing sector. TQM J. 2018, 30, 2-19. [CrossRef]

3. Parmar, P.S.; Desai, T.N. A systematic literature review on Sustainable Lean Six Sigma. Int. J. Lean Six Sigma 2019. [CrossRef]

4. Galli, A.; Wiedmann, T.; Ercin, E.; Knoblauch, D.; Ewing, B.; Giljum, S. Integrating Ecological, Carbon and Water footprint into a "Footprint Family" of indicators: Definition and role in tracking human pressure on the planet. Ecol. Indic. 2012, 16, 100-112. [CrossRef]

5. Bai, X.; Ren, X.; Khanna, N.Z.; Zhou, N.; Hu, M. Comprehensive water footprint assessment of the dairy industry chain based on ISO 14046: A case study in China. Resour. Conserv. Recycl. 2018, 132, 369-375. [CrossRef]

6. Sreedharan, R.; Sandhya, G.; Raju, R. Development of a Green Lean Six Sigma model for public sectors. Int. J. Lean Six Sigma 2018, 9, 238-255. [CrossRef]

7. Tseng, M.L.; Islam, M.S.; Karia, N.; Fauzi, F.A.; Afrin, S. A literature review on green supply chain management: Trends and future challenges. Resour. Conserv. Recycl. 2019, 141, 145-162. [CrossRef]

8. Mangla, S.K.; Luthra, S.; Mishra, N.; Singh, A.; Rana, N.P.; Dora, M.; Dwivedi, Y. Barriers to effective circular supply chain management in a developing country context. Prod. Plan. Control 2018, 29, 551-569. [CrossRef]

9. Garza-Reyes, J.A. Green lean and the need for Six Sigma. Int. J. Lean Six Sigma 2015, 6, 226-248. [CrossRef]

10. Cherrafi, A.; Elfezazi, S.; Chiarini, A.; Mokhlis, A.; Benhida, K. The integration of lean manufacturing, Six Sigma and sustainability: A literature review and future research directions for developing a specific model. J. Clean. Prod. 2016, 139, 828-846. [CrossRef]

11. Banawi, A.; Bilec, M.M. A framework to improve construction processes: Integrating Lean, Green and Six Sigma. Int. J. Constr. Manag. 2014, 14, 45-55. [CrossRef]

12. De Freitas, J.G.; Costa, H.G.; Ferraz, F.T. Impacts of Lean Six Sigma over organizational sustainability: A survey study. J. Clean. Prod. 2017, 156, 262-275. [CrossRef] 
13. Farias, L.M.S.; Santos, L.C.; Gohr, C.F.; de Oliveira, L.C.; da Silva Amorim, M.H. Criteria and practices for lean and green performance assessment: Systematic review and conceptual framework. J. Clean. Prod. 2019, 218, 746-762. [CrossRef]

14. Sony, M.; Naik, S. Green Lean Six Sigma implementation framework: A case of reducing graphite and dust pollution. Int. J. Sustain. Eng. 2019. [CrossRef]

15. Cagno, E.; Trucco, P. Integrated green and quality function deployment. Int. J. Prod. Lifecycle Manag. $2007,2$. [CrossRef]

16. Shih, C.W.; Wang, C.H. Integrating wireless sensor networks with statistical quality control to develop a cold chain system in food industries. Comput. Stand. Interfaces 2016, 45, 62-78. [CrossRef]

17. Garza-Reyes, J.A.; Kumar, V.; Chaikittisilp, S.; Tan, K.H. The effect of lean methods and tools on the environmental performance of manufacturing organisations. Int. J. Prod. Econ. 2018, 200, 170-180. [CrossRef]

18. Al-Sheyadi, A.; Muyldermans, L.; Kauppi, K. The complementarity of green supply chain management practices and the impact on environmental performance. J. Environ. Manag. 2019, 242, 186-198. [CrossRef]

19. Gaikwad, L.; Sunnapwar, V. An integrated Lean, Green and Six Sigma strategies. TQM J. 2020, 32, $201-225$. [CrossRef]

20. Kumar, S.; Luthra, S.; Govindan, K.; Kumar, N.; Haleem, A. Barriers in green lean six sigma product development process: An ISM approach. Prod. Plan. Control 2016. [CrossRef]

21. Cherrafi, A.; Elfezazi, S.; Govindan, K.; Garza-Reyes, J.A.; Benhida, K.; Mokhlis, A. A framework for the integration of Green and Lean Six Sigma for superior sustainability performance. Int. J. Prod. Res. 2016, 55, 4481-4515. [CrossRef]

22. Kaswan, M.S.; Rathi, R. Green Lean Six Sigma for sustainable development: Integration and framework. Environ. Impact Assess. Rev. 2020, 83. [CrossRef]

23. Arroyo, P.; Gonzalez, V. Rethinking waste definition to account for environmental and social impacts. In Proceedings of the 24th Annual Conference of the International Group for Lean Construction, Boston, MA, USA, 18-24 July 2016; pp. 20-22.

24. Hussain, K.; He, Z.; Ahmad, N.; Iqbal, M.; Taskheer Mumtaz, S.M. Green, lean, Six Sigma barriers at a glance: A case from the construction sector of Pakistan. Build. Environ. 2019, 161. [CrossRef]

25. Mishra. Identify critical success factors to implement integrated green and Lean Six Sigma. Int. J. Lean Six Sigma 2018. [CrossRef]

26. Guo, C.; Xu, J.; Yang, L.; Guo, X.; Liao, J.; Zheng, X.; Zhang, Z.; Chen, X.; Yang, K.; Wang, M. Life cycle evaluation of greenhouse gas emissions of a highway tunnel: A case study in China. J. Clean. Prod. 2019, 211, 972-980. [CrossRef]

27. Canellada, F.; Laca, A.; Laca, A.; Diaz, M. Environmental impact of cheese production: A case study of a small-scale factory in southern Europe and global overview of carbon footprint. Sci. Total Environ. 2018, 635, 167-177. [CrossRef]

28. Nguyen, Q.A.; Hens, L. Environmental performance of the cement industry in Vietnam: The influence of ISO 14001 certification. J. Clean. Prod. 2015, 96, 362-378. [CrossRef]

29. De Sousa Jabbour, A.B.L.; Verdério Júnior, S.A.; Jabbour, C.J.C.; Leal Filho, W.; Campos, L.S.; De Castro, R. Toward greener supply chains: Is there a role for the new ISO 50001 approach to energy and carbon management? Energy Effic. 2016, 10, 777-785. [CrossRef]

30. Prasad, S.; Khanduja, D.; Sharma, S.K. An empirical study on applicability of lean and green practices in the foundry industry. J. Manuf. Technol. Manag. 2016, 27, 408-426. [CrossRef]

31. Hines, P. Lean and green. In Source Magazine the Home of Lean Thinking, 3rd ed.; SA Partners: Caerphilly, UK, 2009.

32. Kazancoglu, Y.; Kazancoglu, I.; Sagnak, M. A new holistic conceptual framework for green supply chain management performance assessment based on circular economy. J. Clean. Prod. 2018, 195, 1282-1299. [CrossRef]

33. Womack, J.P.; Jones, D.T.; Roos, D. The Machine That Changed the World: The Story of Lean Production-Toyota's Secret Weapon in the Global Car Wars That is Now Revolutionizing World Industry; Simon and Schuster: New York, NY, USA, 2007.

34. Panwar, A.; Jain, R.; Rathore, A.P.S.; Nepal, B.; Lyons, A.C. The impact of lean practices on operational performance-An empirical investigation of Indian process industries. Prod. Plan. Control 2017, 29, 158-169. [CrossRef] 
35. Alhuraish, I.; Robledo, C.; Kobi, A. A comparative exploration of lean manufacturing and six sigma in terms of their critical success factors. J. Clean. Prod. 2017, 164, 325-337. [CrossRef]

36. Chugani, N.; Kumar, V.; Garza-Reyes, J.A.; Rocha-Lona, L.; Upadhyay, A. Investigating the green impact of Lean, Six Sigma and Lean Six Sigma. Int. J. Lean Six Sigma 2017, 8, 7-32. [CrossRef]

37. Dieste, M.; Panizzolo, R.; Garza-Reyes, J.A.; Anosike, A. The relationship between lean and environmental performance: Practices and measures. J. Clean. Prod. 2019, 224, 120-131. [CrossRef]

38. Ramos, A.R.; Ferreira, J.C.E.; Kumar, V.; Garza-Reyes, J.A.; Cherrafi, A. A lean and cleaner production benchmarking method for sustainability assessment: A study of manufacturing companies in Brazil. J. Clean. Prod. 2018, 177, 218-231. [CrossRef]

39. Hilton, R.J.; Antony, J.; Sohal, A. A conceptual model for the successful deployment of Lean Six Sigma. Int. J. Qual. Reliab. Manag. 2012, 29, 54-70. [CrossRef]

40. Singh, M.; Rathi, R. A structured review of Lean Six Sigma in various industrial sectors. Int. J. Lean SixSigma 2018. [CrossRef]

41. Pacheco, D.; Pergher, I.; Vaccaro, G.L.R.; Jung, C.F.; ten Caten, C. 18 comparative aspects between lean and Six Sigma: Complementarity and implications. Int. J. Lean Six Sigma 2015, 6, 161-175. [CrossRef]

42. Andersson, R.; Mi Dahlgaard-Park, S.; Eriksson, H.; Torstensson, H. Similarities and differences between TQM, six sigma and lean. TQM Mag. 2006, 18, 282-296. [CrossRef]

43. Sagnak, M.; Kazancoglu, Y. Integration of green lean approach with six sigma: An application for flue gas emissions. J. Clean. Prod. 2016, 127, 112-118. [CrossRef]

44. Powell, D.; Lundeby, S.; Chabada, L.; Dreyer, H. Lean Six Sigma and environmental sustainability: The case of a Norwegian dairy producer. Int. J. Lean Six Sigma 2017, 8, 53-64. [CrossRef]

45. Ben Ruben, R.; Vinodh, S.; Asokan, P. Implementation of Lean Six Sigma framework with environmental considerations in an Indian automotive component manufacturing firm: A case study. Prod. Plan. Control 2017, 28, 1193-1211. [CrossRef]

46. Sony, M. Lean Six Sigma in the power sector: Frog into prince. Benchmarking Int. J. 2019, 26, 356-370. [CrossRef]

47. Kaushik, P.; Khanduja, D.; Mittal, K.; Jaglan, P. A case study. TQM J. 2012, 24, 4-16. [CrossRef]

48. Rimantho, D.; Hanantya, M.W. Enhancing the management of the noise level using six sigma method: A case study on the machining industry. IOP Conf. Ser. Mat. Sci. Eng. 2017, 277. [CrossRef]

49. Duarte, S.; Cruz-Machado, V. Modelling lean and green: A review from business models. Int. J. Lean Six Sigma 2013, 4, 228-250. [CrossRef]

50. EPA. The Lean and Environmental Toolkit; United States Environmental Protection Agency: Washington, DC, USA, 2007.

51. Carvalho, H.; Duarte, S.; Machado, V.C. Lean, agile, resilient and green: Divergencies and synergies. Int. J. Lean Six Sigma 2011, 2, 151-179. [CrossRef]

52. Maleyeff, J.; Arnheiter, E.A.; Venkateswaran, V. The continuing evolution of Lean Six Sigma. TQM J. 2012, 24, 542-555. [CrossRef]

53. Klochkov, Y.; Gazizulina, A.; Muralidharan, K. Lean Six Sigma for Sustainable Business Practices: A Case Study and Standardisation. Int. J. Qual. Res. 2019, 13, 47-74. [CrossRef]

54. Salah, S.; Rahim, A.; Carretero, J.A. The integration of Six Sigma and lean management. Int. J. Lean Six Sigma 2010, 1, 249-274. [CrossRef]

55. Assarlind, M.; Gremyr, I.; Bäckman, K. Multi-faceted views on a Lean Six Sigma application. Int. J. Qual. Reliab. Manag. 2013, 30, 387-402. [CrossRef]

56. Kaswan, M.S.; Rathi, R. Analysis and modeling the enablers of Green Lean Six Sigma implementation using Interpretive Structural Modeling. J. Clean. Prod. 2019, 231, 1182-1191. [CrossRef]

57. Chan, C.C.; Yu, K.; Yung, K. Green manufacturing using integrated decision tools. In Proceedings of the 2010 IEEE International Conference on Industrial Engineering and Engineering Management, Macao, China, 7-10 December 2010; pp. 2287-2291.

58. Nunes, B.; Bennett, D. Green operations initiatives in the automotive industry: An environmental reports analysis and benchmarking study. Benchmarking Int. J. 2010, 17, 396-420. [CrossRef]

59. Zhang, Y. Green QFD-II: A life cycle approach for environmentally conscious manufacturing by integrating LCA and LCC into QFD matrices. Int. J. Prod. Res. 1999, 37, 1075-1091. [CrossRef] 
60. Han, S.H.; Chae, M.J.; Im, K.S.; Ryu, H.D. Six sigma-based approach to improve performance in construction operations. J. Manag. Eng. 2008, 24, 21-31. [CrossRef]

61. Ndubisi, N.O.; Nair, S.R. Green entrepreneurship (GE) and green value added (GVA): A conceptual framework. Int. J. Entrep. 2009, 13, 21.

62. Thanki, S.; Thakkar, J. Interdependence analysis of lean-green implementation challenges: A case of Indian SMEs. J. Manuf. Technol. Manag. 2018. [CrossRef]

63. Goyal, A.; Agrawal, R.; Saha, C.R. Quality management for sustainable manufacturing: Moving from number to impact of defects. J. Clean. Prod. 2019, 241. [CrossRef]

64. Snee, R.D. Lean Six Sigma-Getting better all the time. Int. J. Lean Six Sigma 2010, 1, 9-29. [CrossRef]

65. Dües, C.M.; Tan, K.H.; Lim, M. Green as the new Lean: How to use Lean practices as a catalyst to greening your supply chain. J. Clean. Prod. 2013, 40, 93-100. [CrossRef]

66. Green, K.W.; Inman, R.A.; Sower, V.E.; Zelbst, P.J. Impact of JIT, TQM and green supply chain practices on environmental sustainability. J. Manuf. Technol. Manag. 2019, 30, 26-47. [CrossRef]

67. Tranfield, D.; Denyer, D.; Smart, P. Towards a methodology for developing evidence-informed management knowledge by means of systematic review. Br. J. Manag. 2003, 14, 207-222. [CrossRef]

68. Kitchenham, B.; Pearl Brereton, O.; Budgen, D.; Turner, M.; Bailey, J.; Linkman, S. Systematic literature reviews in software engineering-A systematic literature review. Inf. Softw. Technol. 2009, 51,7-15. [CrossRef]

69. Sangwan, K.S.; Mittal, V.K. A bibliometric analysis of green manufacturing and similar frameworks. Manag. Environ. Qual. Int. J. 2015, 26, 566-587. [CrossRef]

70. Verrier, B.; Rose, B.; Caillaud, E. Lean and Green strategy: The Lean and Green House and maturity deployment model. J. Clean. Prod. 2016, 116, 150-156. [CrossRef]

71. Groening, C.; Sarkis, J.; Zhu, Q. Green marketing consumer-level theory review: A compendium of applied theories and further research directions. J. Clean. Prod. 2018, 172, 1848-1866. [CrossRef]

72. Moher, D.; Liberati, A.; Tetzlaff, J.; Altman, D.G. Preferred reporting items for systematic reviews and meta-analyses: The PRISMA statement. Int. J. Surg. 2010, 8, 336-341. [CrossRef]

73. Berenson, M.L.; Levine, D.M. Basic Business Statistics: Concepts and Applications; Prentice-Hall: Englewood Cliffs, NJ, USA, 1989.

74. Rauch, E.; Dallasega, P.; Matt, D.T. Sustainable production in emerging markets through Distributed Manufacturing Systems (DMS). J. Clean. Prod. 2016, 135, 127-138. [CrossRef]

75. Luken, R.; Van Rompaey, F. Drivers for and barriers to environmentally sound technology adoption by manufacturing plants in nine developing countries. J. Clean. Prod. 2008, 16, S67-S77. [CrossRef]

76. Creswell, J.W.; Hanson, W.E.; Clark Plano, V.L.; Morales, A. Qualitative Research Designs. Couns. Psychol. 2016, 35, 236-264. [CrossRef]

77. Yin, R.K. Applications of Case Study Research; Sage: Los Angeles, CA, USA, 2011.

78. Turner III, D.W. Qualitative interview design: A practical guide for novice investigators. Qual. Rep. 2010, 15, 754-760.

79. Caiado, R.; Quelhas, O.L.G.; Nascimento, D.; Anholon, R.; Leal Filho, W. Towards sustainability by aligning operational programmes and sustainable performance measures. Prod. Plan. Control 2019, 30, 413-425. [CrossRef]

80. Zhu, Q.; Johnson, S.; Sarkis, J. Lean six sigma and environmental sustainability: A hospital perspective. Supply Chain Forum Int. J. 2018, 19, 25-41. [CrossRef]

81. Ruben, B.; Vinodh, S.; Asokan, P. Lean Six Sigma with environmental focus: Review and framework. Int. J. Adv. Manuf. Technol. 2017, 94, 4023-4037. [CrossRef]

82. Niñerola, A.; Ferrer-Rullan, R.; Vidal-Suñé, A. Climate Change Mitigation: Application of Management Production Philosophies for Energy Saving in Industrial Processes. Sustainability 2020, 12, 717. [CrossRef]

83. Chaplin, L.; Rourke, S.T.J. Could lean and green be the driver to integrate business improvement throughout the organisation? Int. J. Product. Perform. Manag. 2018, 67, 207-219. [CrossRef]

84. Sarkis, J.; Pati, N.; Bai, C.; Jabbour, A.B.L.d.S.; Jabbour, C.J.C.; Sobreiro, V.A. Connecting the pieces of the puzzle toward sustainable organizations. Benchmarking Int. J. 2016, 23, 1605-1623. [CrossRef]

85. Yadav, R.; Varghese, V.; Pareek, S. Six Sigma in the context of Environmental Management System-A mechanism design approach. Int. J. Pure Appl. Manag. Sci. 2016, 1, $26-38$.

86. Fai Pun, K. Determinants of environmentally responsible operations: A review. Int. J. Qual. Reliab. Manag. 2006, 23, 279-297. [CrossRef] 
87. Furukawa Pde, O.; Cunha, I.C.; Pedreira Mda, L. Evaluation of environmentally sustainable actions in the medication process. Rev. Bras. Enferm. 2016, 69, 16-22. [CrossRef]

88. Tasdemir, C.; Gazo, R. Validation of Sustainability Benchmarking Tool in the Context of Value-Added Wood Products Manufacturing Activities. Sustainability 2019, 11, 2361. [CrossRef]

89. Marrucci, L.; Marchi, M.; Daddi, T. Improving the carbon footprint of food and packaging waste management in a supermarket of the Italian retail sector. Waste Manag. 2020, 105, 594-603. [CrossRef] [PubMed]

90. Kaswan, M.S.; Rathi, R. Investigating the enablers associated with implementation of Green Lean Six Sigma in manufacturing sector using Best Worst Method. Clean Technol. Environ. Policy 2020. [CrossRef]

91. Ruben, B.; Vinodh, S.; Asokan, P. ISM and Fuzzy MICMAC application for analysis of Lean Six Sigma barriers with environmental considerations. Int. J. Lean Six Sigma 2018, 9, 64-90. [CrossRef]

92. Caiado, R.; Nascimento, D.; Quelhas, O.; Tortorella, G.; Rangel, L. Towards Sustainability through Green, Lean and Six Sigma Integration at Service Industry: Review and Framework. Technol. Econ. Dev. Econ. 2018, 24, 1659-1678. [CrossRef]

93. De Oliveira Furukawa, P.; Cunha, I.; Pedreira, M.; Marck, P.B. Characteristics of nursing professionals and the practice of ecologically sustainable actions in the medication processes. Rev. Lat. Am. Enferm. 2017, 25, e2909. [CrossRef]

94. Pal Pandi, A.; Rajendra Sethupathi, P.V.; Jeyathilagar, D. The IEQMS model for augmenting quality in engineering institutions-An interpretive structural modelling approach. Total Qual. Manag. Bus. Excell. 2014, 27, 292-308. [CrossRef]

95. Erdil, N.O.; Aktas, C.B.; Arani, O.M. Embedding sustainability in lean six sigma efforts. J. Clean. Prod. 2018, 198, 520-529. [CrossRef]

96. Portela, P.P.; Mussi, F.C.; Gama, G.G.G.; Santos, C.A.D.S.T. Fatores associados ao descontrole da pressão arterial em homens. Acta Paul. Enferm. 2016, 29, 307-315. [CrossRef]

97. Mishra, K.A.; Sharma, A.; Sachdeo, M.; Kandasamy, J. Development of sustainable value stream mapping (SVSM) for unit part manufacturing. Int. J. Lean Six Sigma 2019, 11, 493-514. [CrossRef]

98. Belhadi, A.; Kamble, S.S.; Zkik, K.; Cherrafi, A.; Touriki, F.E. The integrated effect of Big Data Analytics, Lean Six Sigma and Green Manufacturing on the environmental performance of manufacturing companies: The case of North Africa. J. Clean. Prod. 2020, 252. [CrossRef]

99. Fatemi, S.; Franchetti, M.J. An application of sustainable lean and green strategy with a Six Sigma approach on a manufacturing system. Int. J. Six Sigma Compet. Advant. 2016, 10, 62. [CrossRef]

100. Kendrick, B.A.; Dhokia, V.; Newman, S.T. Strategies to realize decentralized manufacture through hybrid manufacturing platforms. Robot. Comput. Integr. Manuf. 2017, 43, 68-78. [CrossRef]

101. Ratnayake, R.M.C.; Chaudry, O. Maintaining sustainable performance in operating petroleum assets via a lean-six-sigma approach. Int. J. Lean Six Sigma 2017, 8, 33-52. [CrossRef]

102. Martin, D.M.; Yanez, N.D.; Treggiari, M.M. An Initiative to Optimize Waste Streams in the Operating Room: RECycling in the Operating Room (RECOR) Project. Am. Assoc. Nurse Anesth. 2017, 85, 108-112.

103. Belamkar, N. development of green high performance liquid chromatographymethod for determination for ranitidine hydrochloride in solid dosage form by applying lean sigma principles. Res. J. Pharm. Biol. Chem. Sci. 2016, 7, 1949-1961.

104. Aldairi, J.; Khan, M.K.; Munive-Hernandez, J.E. Knowledge-based Lean Six Sigma maintenance system for sustainable buildings. Int. J. Lean Six Sigma 2017, 8, 109-130. [CrossRef]

105. Galeazzo, A.; Furlan, A.; Vinelli, A. Lean and green in action: Interdependencies and performance of pollution prevention projects. J. Clean. Prod. 2014, 85, 191-200. [CrossRef]

106. Chiarini, A. Sustainable manufacturing-greening processes using specific Lean Production tools: An empirical observation from European motorcycle component manufacturers. J. Clean. Prod. 2014, 85, 226-233. [CrossRef]

107. Duflou, J.R.; Sutherland, J.W.; Dornfeld, D.; Herrmann, C.; Jeswiet, J.; Kara, S.; Hauschild, M.; Kellens, K. Towards energy and resource efficient manufacturing: A processes and systems approach. CIRP Ann. 2012, 61, 587-609. [CrossRef]

108. Orji, I.J. Examining barriers to organizational change for sustainability and drivers of sustainable performance in the metal manufacturing industry. Resour. Conserv. Recycl. 2019, 140, 102-114. [CrossRef]

109. Jasiulewicz-Kaczmarek, M.; Legutko, S.; Kluk, P. Maintenance 4.0 technologies-new opportunities for sustainability driven maintenance. Manag. Prod. Eng. Rev. 2020, 11, 74-87. 
110. Muhuri, P.K.; Shukla, A.K.; Abraham, A. Industry 4.0: A bibliometric analysis and detailed overview. Eng. Appl. Artif. Intell. 2019, 78, 218-235. [CrossRef]

111. Yin, Y.; Stecke, K.E.; Li, D. The evolution of production systems from Industry 2.0 through Industry 4.0. Int. J. Prod. Res. 2017, 56, 848-861. [CrossRef]

112. Buer, S.V.; Strandhagen, J.O.; Chan, F.T.S. The link between Industry 4.0 and lean manufacturing: Mapping current research and establishing a research agenda. Int. J. Prod. Res. 2018, 56, 2924-2940. [CrossRef]

113. Jasiulewicz-Kaczmarek, M.; Gola, A. Maintenance 4.0 Technologies for Sustainable Manufacturing-An Overview. IFAC-PapersOnLine 2019, 52, 91-96. [CrossRef]

114. De Sousa Jabbour, A.B.L.; Jabbour, C.J.C.; Foropon, C.; Godinho Filho, M. When titans meet-Can industry 4.0 revolutionise the environmentally-sustainable manufacturing wave? The role of critical success factors. Technol. Forecast. Soc. Chang. 2018, 132, 18-25. [CrossRef]

115. Dubey, R.; Gunasekaran, A.; Childe, S.J.; Papadopoulos, T.; Luo, Z.; Wamba, S.F.; Roubaud, D. Can big data and predictive analytics improve social and environmental sustainability? Technol. Forecast. Soc. Chang. 2019, 144, 534-545. [CrossRef]

116. Gaustad, G.; Krystofik, M.; Bustamante, M.; Badami, K. Circular economy strategies for mitigating critical material supply issues. Resour. Conserv. Recycl. 2018, 135, 24-33. [CrossRef]

117. Nadeem, S.P.; Garza-Reyes, J.A.; Anosike, A.I.; Kumar, V. Coalescing the lean and circular economy. In Proceedings of the International Conference on Industrial Engineering and Operations Management, Bangkok, Thailand, 5-7 March 2019.

118. Nagalingam, S.V.; Kuik, S.S.; Amer, Y. Performance measurement of product returns with recovery for sustainable manufacturing. Robot. Comput. Integr. Manuf. 2013, 29, 473-483. [CrossRef]

119. EC. Communication from the Commission to the European Parliament, the Council, the European Economic and Social Committee and the Committee of the Regions: On the Implementation of the Circular Economy Action Plan; Publications Office of the European Union: Brussels, Belgium, 2019.

(C) 2020 by the authors. Licensee MDPI, Basel, Switzerland. This article is an open access article distributed under the terms and conditions of the Creative Commons Attribution (CC BY) license (http://creativecommons.org/licenses/by/4.0/). 